Document downloaded from:

http://hdl.handle.net/10251/36956

This paper must be cited as:

Ferreira, T.; García-Arias, A.; Francés, F.; Egger, G.; Garófano-Gómez, V.; MartinezCapel, F.; Andrés Doménech, I.... (2013). Implementing a dynamic riparian vegetation model in three European river systems. Ecohydrology. 6(4):635-651.

doi:10.1002/eco.1331.

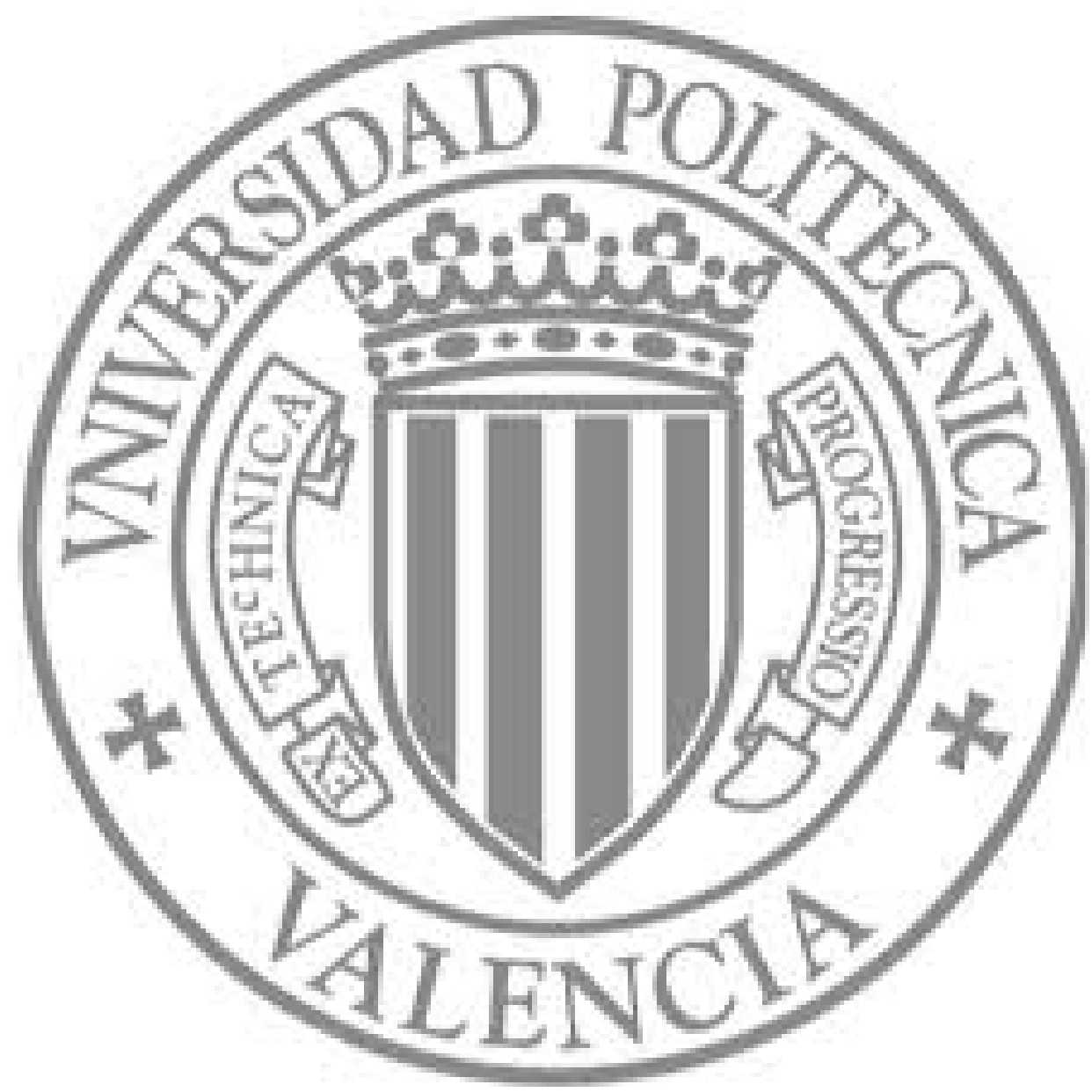

The final publication is available at

http://dx.doi.org/10.1002/eco.1331

Copyright Wiley-Blackwell 
This is a pre-copyedited, author-produced PDF version following peer review of the article: García-Arias A., Francés F., Ferreira T., Egger G., Martínez-Capel F., Garófano-Gómez V., AndrésDoménech I., Politti E., Rivaes R., Rodríguez-González P.M. (2013). Implementing a dynamic riparian vegetation model in three European river systems. Ecohydrology, 6(4):635-651. doi: 10.1002/eco.1331, which has been published in definitive publisher-authenticated form at http://onlinelibrary.wiley.com/doi/10.1002/eco.1331/abstract

Article first published online 18 OCT 2012 by John Wiley \& Sons, Ltd. All rights reserved. All further use of this material other than for personal research is subject to permission from the publisher.

\title{
Implementing a dynamic riparian vegetation model in three European river systems
}

\author{
A. García-Arias ${ }^{1}$, F. Francés $^{1}$, T. Ferreira ${ }^{2}$, G. Egger ${ }^{3}$, F. Martínez-Capel ${ }^{4}$, \\ V. Garófano-Gómez ${ }^{4}$, I. Andrés-Doménech ${ }^{1}$, E. Politti $^{3}$, R. Rivaes ${ }^{2}$ and P. M. \\ Rodríguez-González². \\ ${ }^{1}$ Research Institute of Water and Environmental Engineering, Universitat Politècnica de \\ València, Camino de Vera s/n, 46022, Valencia, Spain. \\ ${ }^{2}$ Forest Research Center. Instituto Superior de Agronomia. Technical University of Lisbon. \\ Tapada da Ajuda 1349-017, Lisboa, Portugal. \\ ${ }^{3}$ Environmental Consulting Klagenfurt, Bahnhofstrasse 39, 9020 Klagenfurt, Austria. \\ ${ }^{4}$ Research Institute for Integrated Management of Coastal Areas, Universitat Politècnica de \\ València, C/ Paranimf, 1, 46730 Grao de Gandia (Valencia), Spain. \\ * Correspondence to: Alicia García-Arias. Universitat Politècnica de València - Edificio 4E \\ Planta 1, Camino de Vera s/n, 46022, Valencia, Spain. E-mail: algarar2@upv.es. Telephone: \\ +34 963877000 (Ext.:76152). Fax: +34 963877618 (Ext.:77618)
}

\begin{abstract}
Riparian ecosystems are required to be preserved to achieve the good ecological status. The Water Framework Directive (WFD 2000/60/EC) specifically supports the assessment of new management tools that allow the European Member States to achieve the good ecological status of the river related ecosystems. Within several approaches, a dynamic riparian vegetation distributed model (CASiMiR-vegetation), with a time step of one year, has been selected as a useful first-step tool to achieve the WFD requirements. The model has been implemented into three river reaches with different climatic and hydrologic settings, located in three European countries. Common bases were established in the model set-up. The model was calibrated independently in the Kleblach reach (Drau River, Austria), the Ribeira reach (Odelouca River, Portugal), and the Terde reach (Mijares River, Spain) with simulation periods of 8,11 and 41 years respectively. The parameters values and the results were comparable between the different countries. The calibration performance achieved high correctly classified instances $(\mathrm{CCl} \approx 60 \%)$. Additionally, weighted kappa values ranged from 0.52 to 0.66 in distinguishing riparian succession phases. The model behaved similarly in the validation, even offering better results in most cases. This work demonstrates the applicability of this model in
\end{abstract}


the simulation of the riparian vegetation dynamic distribution over a wide range of environments. As it performs in a robust manner and with good results in reaches with different hydrological characteristics, the model could be also applied to analyze different hydrological scenarios or to predict changes after restoration measures within a reach.

KEYWORDS riparian vegetation; succession/retrogression; dynamic modelling; model implementation; river systems management

\section{INTRODUCTION}

Riparian ecosystems are coupled to streams, they depend on the hydrological regime and they also are key elements in the water cycle. Within riparian ecosystems, the riparian vegetation exerts an essential role in sediment retention processes (Naiman et al., 2002; Hupp and Rinaldi, 2010), water quality control (Altier et al., 2002; Rayne et al., 2008; Medici et al., 2010) and fauna habitat distribution along the river (Naiman et al., 2005). Riparian species have developed adaptations and synchronized life-history traits with the variable conditions of the river dynamics (Stella et al., 2006). When the fluvial characteristics are modified, riparian plant communities and vegetation structure change favouring less bio-diverse environments, worse water quality and more exposed river beds (Bornette and Puijalon, 2011); definitely leading to a poor or bad ecological status. To achieve the good ecological status of a water body, in most cases can be crucial to preserve the riparian vegetation in order to support its hydrological and ecological functions. But this is not an easy task and often water management does not consider the complexity and multiple processes that take place in the riparian ecosystems (Naiman et al., 2005).

One of the greatest challenges to make progress in the riparian ecosystem preservation and restoration is to understand the physical and ecological processes of the system, and the interactions and feedbacks within these processes (Corenblit et al., 2007, 2011; Darby and Sear, 2008). It is equally important to recognize the specific disturbances that alter the system. For management purposes, the importance of a framework for a systematic analysis of river ecosystems has been emphasized (Goodwin and Hardy, 1999). The Water Framework Directive (WFD 2000/60/EC) supports this idea, requiring the development of new management tools to allow the European Member States to achieve the good ecological status of river related ecosystems.

In this context, mathematical models bring us the possibility of gaining insight on the simulated ecosystem state variables and to forecast the effects due to the variation of its driving forces (Perona et al., 2009). In most vegetation models, the growth is limited by the maximum of the moisture, nutrients, light and temperature stresses, so if one dominates, the others have a lesser role (Altier et al., 2002; Neitsch et al., 2002). However, close to the rivers, plant survival is clearly not due exclusively to the water availability; also the frequency, duration and magnitude of floods are conditioning factors for a wellbalanced riparian vegetation dynamics (Tabacchi et al., 1998; Gergel et al., 2002; Rood et al., 2003). During last years, a variety of ecological models have evolved to address changes in vegetation species as consequence of changes 
in environmental variables and hydrological alterations (Franz and Bazzaz, 1977; Pearlstine et al., 1985; Auble et al. 1994; Mahoney and Rood, 1998; Altier et al., 2002; Braatne et al., 2002; Baptist and De Jong, 2005; Glenz, 2005; Hooke et al., 2005; Murphy et al., 2006). A common feature for such mathematical models is the conceptualization of the functional relationships between hydrology and vegetation species or communities. Among the most recent ones, the CASiMiR-vegetation model (Computer Aided Simulation Model for In-stream flow and Riparia), proposed by Benjankar et al. (2011) stands out. It is a rule based and spatially explicit dynamic vegetation model which accounts for recruitment, succession and retrogression of the riparian vegetation according to spring mean flow level, morphodynamic disturbance and physiological stress, which are the main driving forces controlling the riparian vegetation. Therefore, Benjankar's model is theoretically applicable to riparian ecosystems from different ecoregions; however, such transposable applicability has not been so far tested and the model lacks a conceptual validation.

The overall objective of the present research was filling this gap by attempting the application of the same model to riparian ecosystems found in different climatic contexts and characterized by different vegetation, geomorphic and hydrological contexts. This paper presents some of the results achieved within the RIPFLOW project, in which the Benjankar et al. (2011) modelling approach was implemented in three European case studies located in Austria, Portugal and Spain.

\section{MODEL DESCRIPTION}

The CASiMiR-vegetation model (Benjankar et al., 2011) is a dynamic floodplain vegetation model that incorporates the essential riparian ecosystem driving forces and the key parameters related with the behaviour of riparian ecosystems at reach scale. The model assumes that vegetation development depends on the functional relationship between hydrology, physical processes, and vegetation communities. In the model conceptualization, physical processes are represented by height above the base/mean water level (base water level for Mediterranean environments and mean water level for Alpine environments) and shear stress, regulating the successful recruitment and development of the vegetation or its retrogression to the initial stage. Benjankar et al. (2011) implementation included also the effect of flood duration but this feature has not been applied, since preliminary analyses indicated that there were not floods long enough to cause impacts on any of the study sites. The main state variable of the model representing riparian vegetation is categorical and the categories correspond to the different succession phases observed in typical riparian vegetation succession lines. These succession phases are species assemblages defined according to their colonization strategy and development stage. They are also characterized by critical values of the disturbance indicators, allowing the progression/retrogression decision making within the model.

Model implementation is made up by a static and a dynamic module (Figure 1). The static module defines the starting vegetation types (succession phases) and their minimum ages in the study area. These minimum ages are taken from the age spans related to each succession phase that must have been 
previously defined. Static component output is meant to be used as input for the dynamic component. The rules, on which this version of the model proposed by Benjankar et al. (2011) is based, can be briefly described as follows. Yearly height above the base/mean flow influences the recruitment and the scour disturbance applied to seedlings. The vegetation is considered to be impacted by floods through shear stress. Critical shear stress values are assigned to the different phases of the succession. These threshold values of shear stress represent the resistance of each succession phase. The model considers by default the vegetation removal under the hardest flood of every year and limits this removal through the critical shear stress values establishment. Thus, when the shear stress is strong enough, higher than the critical shear stress values, it causes disruption of the vegetation and consequent retrogression of the stands to initial phase (bare soil). The model time step is one year. If no disturbances take place, the vegetation get older (year step) and progress to the next succession phase in the succession-retrogression scheme, where three succession series (in different lines but with possible connections) can be defined: woodland, reed and wetland series.

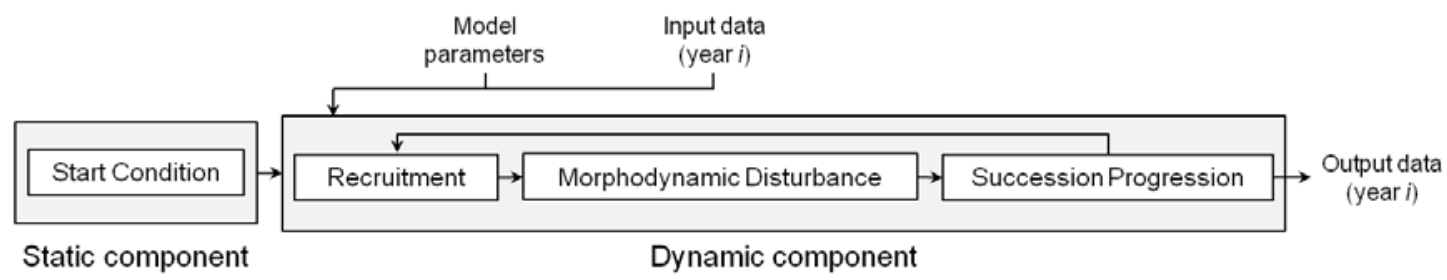

Figure 1. CASiMiR-vegetation model scheme.

\section{STUDY SITES}

The study sites selection in the three considered countries (Austria, Portugal and Spain) was made looking for different climate and flow regime conditions for the model calibration and validation. The selected locations had to satisfy several requirements, such as availability of flow time series long enough in at least one reliable gauging station, a good ecological status with natural dynamism (geomorphological processes) still prevailing, natural variety of succession phases and easy accessibility.

The riparian vegetation distribution patterns under study corresponded to the lateral zonation on the transversal gradient, which is more characteristic for the reach scale, because it depends on the local conditions (Malanson, 1993; Naiman et al., 2005). If we intended to study the longitudinal variability of the different types of riparian vegetation zonation, higher lengths would be needed since the longitudinal gradient relies more on the regional scale physical gradients (Malanson, 1993). Taking this into account, the minimum area to be assessed in each study site was carefully studied. Firstly, the area should embrace all typical succession phases existing in the studied river. Secondly, lateral boundaries wider that a 50-year floodplain margins were considered necessary to observe developmental processes in riparian vegetation succession (Frissell et al., 1986). Lastly, especially in the most dynamic area in river systems such as the bank zone, a river length with ten to fifteen times the channel width should include proportionally all different habitats existing in the river system (Bovee, 1977). Accounting for these concerns, the minimum study 
site width was defined by the presence of terrestrial vegetation or the 100-year return period discharge. In terms of longitudinal dimension, the length of the three study sites (Figure 2) ranged between 400 and $700 \mathrm{~m}$, following the Bovee (1977) recommendation.

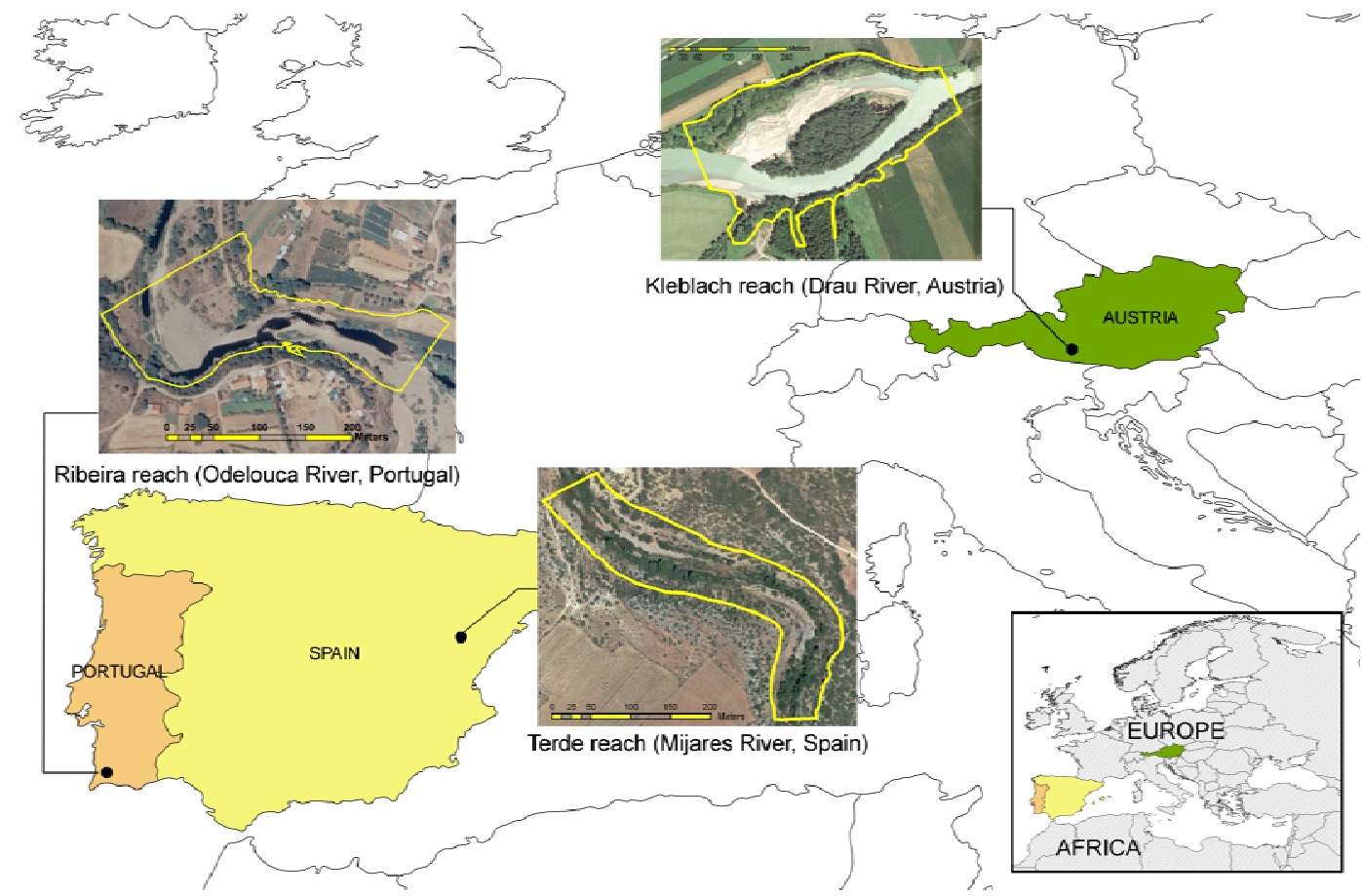

Figure 2. Location of the three study sites: Kleblach reach (Drau River, Austria), Ribeira reach (Odelouca River, Portugal) and Terde reach (Mijares River, Spain).

Kleblach reach (Drau River, Austria). This case study is located in the upper course of the Drau River, near the village of Lind, Austria. The site length is about $700 \mathrm{~m}$ and the altitude is approximately $570 \mathrm{~m}$ above sea level (masl). In historic times, the upper Drau had braided sections with side arms and gravel bars, but during the $20^{\text {th }}$ century it was canalized with consequent removal of these side arms, loss of habitats and ultimately species decline (Formann et al., 2007). The hydrological regime of the Drau reach has its maximum discharge in June, while over winter discharge values are moderate with a $74 \mathrm{~m}^{3} / \mathrm{s}$ mean value and a $320 \mathrm{~m}^{3} / \mathrm{s}$ bankfull discharge. Peak flows close to $2000 \mathrm{~m}^{3} / \mathrm{s}$ have been observed in this reach. Kleblach study site was restored in 2002, the implemented measures included the removal of bank protection, the excavation of a side channel and the removal of vegetation from the bank zone.

Ribeira reach (Odelouca River, Portugal). This study site is located in the middle course of the Odelouca River, near Ribeira village, Portugal. The site length is approximately $400 \mathrm{~m}$ and the altitude is about 132 masl. It is a natural meandering segment with no canalization. The Ribeira reach presents a typical unregulated Mediterranean hydrological regime with a mean annual discharge of $2.5 \mathrm{~m}^{3} / \mathrm{s}$, varying from a null discharge in summer, up to values between 80 and $480 \mathrm{~m}^{3} / \mathrm{s}$ (regular and 100-year period discharges) when winter flash floods occur.

Terde reach (Mijares River, Spain). This study site is located in the upper course of the Mijares River, between the villages of Sarrión and Mora de 
Rubielos, Spain. The site length is $539 \mathrm{~m}$ and the altitude is 850 masl. It is also a natural meandering segment with no canalization. The Terde reach is free from flow regulation and its hydrological regime shows notable discharge intraand inter-annual variability, characteristic of Mediterranean watersheds. The reach has permanent flow, being $0.894 \mathrm{~m}^{3} / \mathrm{s}$ the mean annual discharge and 5 $\mathrm{m}^{3} / \mathrm{s}$ the estimated bankfull discharge. Floods up to $650 \mathrm{~m}^{3} / \mathrm{s}$ instantaneous flows have been observed in this site.

\section{MODEL INPUTS DEFINITION}

The input maps were generated as described below, sharing the same pixel size of $1 \mathrm{~m}$ in the three case studies.

Topographical inputs. The digital elevation model (DEM) and the riverine zones maps (named: aquatic zone AZ, bank zone BZ and floodplain zone FPZ) are the topographical inputs of CASiMiR-vegetation model. These maps did not change during the simulation period in those cases where the river morphology was very stable (i.e. Spanish and Portuguese case studies), implying stationary assumptions for the river morphology. We assumed constant floodplain geomorphology in these study sites based on two main reasons. Firstly, though spatial trends tend to change continuously over time, they are expected to be similar in a short timeframe (Wildi, 2010). At a landscape level, patch area balance can be considered to remain relatively stable, according to the shifting habitat mosaic concept (Stanford et al., 2005; Tockner et al., 2010). Therefore, although changes in channel morphology could modify patch disposal, it is not expected to substantially change the area balance of the succession phases. Secondly, according to the existing aerial photographs, we were able to realize that river stretches maintained approximately the same topography. This hypothesis was proven when analyzing the model accuracy results. In other words, small changes in topographical inputs were not significantly influent in the dynamic distribution of riparian communities. On the contrary, for the Austrian reach, where the river morphology changes significantly after big floods, two different available DEMs were used. In order to determine the AZ, the mean annual flow was considered in this Alpine site, while the base flow was taken into account in the Mediterranean sites (Spain and Portugal), because there is a significant difference between mean and base flow and the later is an important reference for the summer conditions in Mediterranean ecosystems.

Hydraulic inputs. The surface water elevations (and the corresponding depths) were obtained by performing 2D hydraulic simulations for each simulated flow. From them, the water table elevations (WTE) were interpolated horizontally, assigning, by the Thiessen proximity algorithm, the nearest water elevation in the channel to its nearest dry bank zone, up to model boundaries. According to water depths and velocities obtained from hydraulic simulations, shear stress (SS) were deducted by means of the relation with the shear velocities $\left(u^{*}[\mathrm{~m} / \mathrm{s}]\right)$, $S S=\rho \cdot u^{* 2}$, where $\rho$ is the water density $\left(\mathrm{kg} / \mathrm{m}^{3}\right)$. Classifications by type of hydrological year (based on flow regime analyses) were made in order to simplify the assignment of the yearly WTE maps. Moreover, the SS maps $\left(\mathrm{N} / \mathrm{m}^{2}\right)$ were developed considering representative maximum yearly flows. 
Vegetation maps (succession phases). Through aerial photographs analyses, field survey of the vegetation patches and estimated growth curves, observed vegetation maps were developed based on the definition of succession phases (adapted from Kovalchik and Clausnitzer, 2004; Naiman et al., 2005; Egger et al., 2009). Vegetation patches were defined as homogeneous units with a similar elevation, soil and vegetation characteristics, considering up to three different succession lines: woodland, wetland and reed (more details about the vegetation survey can be found in Garófano-Gómez et al., 2011). Succession lines present three stages: colonization, transition and mature-climax stages. The colonization stage represents the beginning of the succession. It starts when the seedlings begin to colonize the bare sediments, i.e. the initial phase (IP), when hardly any plants are observed. The second phase in the succession is the pioneer phase (PP), characterized by relatively low and sparse vegetation of either ruderal or stress-tolerant species. The transition stage, also called consolidation stage (Naiman et al., 2005), is reached after some years of a high biomass production. In the first phase, the vegetation cover overpass $30 \%$ of the surface and herbaceous short-lived species dominate (herb phase, HP), while pioneer shrubs can also grow; in the following years, some woody and long-lived species grow higher than herbs, i.e. the shrub phase, SP. In the herb phase, the species of reed may dominate and form a mono-specific and very stable habitat; if some shrubs can grow in there, the herb reed phase $\left(\mathrm{HP}^{*}\right)$ can progress to the shrub reed phase $\left(\mathrm{SP}^{*}\right)$, as it is further explained below. Later, when trees (typically willows and poplars) replace the shrubs as the dominant life form, it is the early successional woodland phase (ES), also named stem exclusion phase (see Naiman et al., 2005). It is followed by the established forest phase, EF (understory re-initiation phase, see Oliver and Larson, 1996), more stable and less disturbed, when the hardwood forest dominates. The mature stage is the third one, characterized by lower biomass production and larger standing biomass. The first phase is the mature mixed forest (MF), in which competitive woody and long-lived species dominate. In the Terde reach, we can also find the climax stage, consisting of the terrestrial upland forest phase (UF), i.e. the zonal vegetation. The succession phases are further explained in each of the study sites.

Succession-retrogression schemes. The age spans of the succession phases are necessary rules in the model, based on a field survey. The processing of field data started with the adjustment of growth functions (age as function of DBH -diameter at breast height- and height) based on core sampling in the indicator species (see Garófano-Gómez et al., 2009), which were used to estimate the minimum and maximum ages of every patch. The abundances of species, coverage and dominant species, and the estimated age, were used to determine the succession phase in a habitat patch. Then, the corresponding age intervals were assigned to the succession phases. When disturbances take place, retrogressions may occur. If there are no retrogressions and the succession continues progressing, the woodland series achieves the climax, being its typical species replaced by zonal terrestrials and corresponding to UF, the last succession phase. The succession-retrogression schemes are also required as a model input. The main guidelines to build these schemes were two: colonization stage must include common phases for every series observed in a study site; and the retrogressions due to shear stress impacts (vegetation removal) must end up leading to a bare soil (IP). 
The model set up implied the gathering of the input data with slightly different methodologies by each country. The main distinctions took place regarding the hydrological characteristics of each study site and the differences between the observed vegetation, as described below. Nevertheless, the guidelines described above were always followed.

Model inputs for the Kleblach reach study site.

In the Kleblach reach (Drau River, Austria) the daily flows between 2000 and 2008 (Figure 3) were considered to produce the riverine zones topographical and hydraulic inputs. These data were collected at the Sachsenburg gauging station, which covers a draining basin area of $2561 \mathrm{~km}^{2}$ and is located near and upstream of the study site. This dynamic reach required two sets of topographical inputs, due to the important morphological changes observed in 2007. Indeed, the 2003 DEM was used for the simulated time span previous to 2007, while after 2007 the morphology measured in 2008 was used. The heights of the mean flow determined the AZ. The BZ was defined as the area covered by a $380 \mathrm{~m}^{3} / \mathrm{s}$ bankfull discharge, excluded the AZ. Finally, the FPZ was defined by exclusion. Hydrodynamics were simulated using the two dimensional numerical flow model RSim-2D, as a part of the RSim river modelling framework (Tritthart, 2005). The applied integrated hydrodynamicnumerical model is based on the Finite Element method, a triangular mesh, and the Smagorinsky turbulence closure and delivers depth-averaged flow velocities. Several discharge classes between mean discharge and the flow corresponding to a 300-year return period flood were modeled. The resulting flow variables were water surface elevation maps and shear velocity maps corresponding to different discharge classes. The WTE maps were approximated by the water surface elevations related to five discharge classes $\left(80,100,125,140,160 \mathrm{~m}^{3} / \mathrm{s}\right)$. The SS maps were calculated for the yearly peak flows, obtaining ten maps equivalent to peak flows between 270 and $1980 \mathrm{~m}^{3} / \mathrm{s}$.

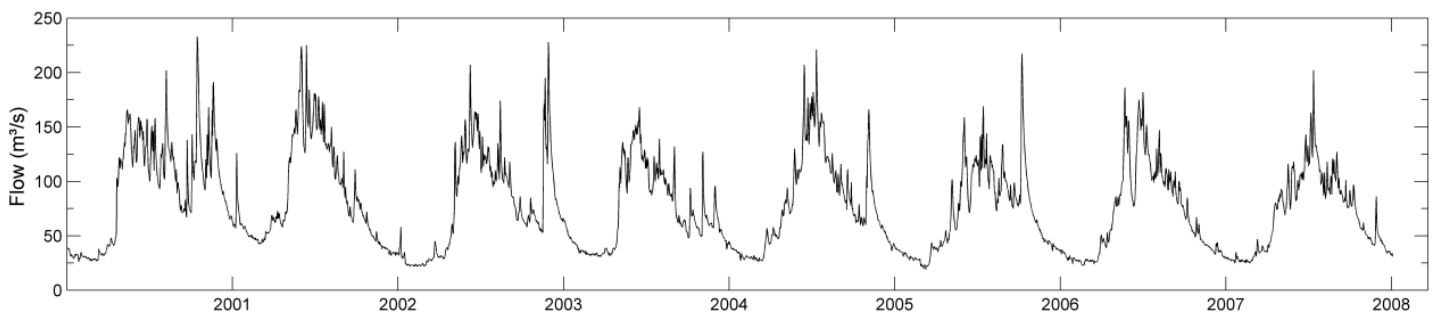

Figure 3. Daily river discharges $\left(\mathrm{m}^{3} / \mathrm{s}\right)$ in the Kleblach reach (Drau River, Austria). Period: 20002008.

Since this study site was restored in 2002, it has been subject to constant post project monitoring which witnessed the establishment and turnover of vegetation and riparian features. Its vegetation was yearly sampled from 2003 to 2010. Three succession lines were identified: woodland, reed and wetland series. The end of the progression in the woodland series was the climax of the ecosystem. The age span of the succession phases in each series is detailed in Table 1. The IP was characterized by sand and gravel bars (no vegetation). The vegetation observed in the PP mainly included tamarisks, bentgrass and willows on several associations. In the reed series, $\mathrm{HP}^{*}$ was dominated by purple reedgrass (Calamagrostietum pseudophragmites (Haller f.) Koeler). In the 
woodland series, the HP was defined as pioneer shrub phase (PS), dominated by tamarisks and willows. The SP was mainly represented by tamarisk (Myricaria germanica (L.) Desv), almond willow (Salix triandra L.), purple willow (Salix purpurea L.) and rosemary willow (Salix eleagnos Scop.), while the ES was dominated by the white willow (Salix alba L.) and the and the grey alder (Alnus incana (L.) Moench). Finally, in the woodland series, the EF may include the grey alder, European ash (Fraxinus excelsior L.) and Norway spruce (Picea abies (L.) Karst). Within the wetland series in the floodplain zone, there were three succession phases: deep oxbow phase (DO), shallow oxbow phase (SO), and bog forest phase (BF) characterized by European alder (Alnus glutinosa (L.) Gaertn).

Table 1. Succession phases according to the succession stages and succession series, with the age interval (minimum, maximum) in the three study sites, Kleblach reach (Drau River, Austria), Ribeira reach (Odelouca River, Portugal) and Terde reach (Mijares River, Spain).

\begin{tabular}{|c|c|c|c|c|c|c|c|}
\hline \multirow[b]{2}{*}{ Stage } & \multirow[b]{2}{*}{ Phase } & \multicolumn{2}{|c|}{$\begin{array}{l}\text { Kleblach reach } \\
\text { (Drau River, } \\
\text { Austria) }\end{array}$} & \multicolumn{2}{|c|}{$\begin{array}{l}\text { Ribeira reach } \\
\text { (Odelouca River, } \\
\text { Portugal) }\end{array}$} & \multicolumn{2}{|c|}{$\begin{array}{l}\text { Terde reach } \\
\text { (Mijares River, } \\
\text { Spain) }\end{array}$} \\
\hline & & $\begin{array}{l}\text { Min. } \\
\text { age }\end{array}$ & $\begin{array}{l}\text { Max. } \\
\text { age }\end{array}$ & $\begin{array}{l}\text { Min. } \\
\text { age }\end{array}$ & $\begin{array}{l}\text { Max. } \\
\text { age }\end{array}$ & $\begin{array}{l}\text { Min. } \\
\text { age }\end{array}$ & $\begin{array}{l}\text { Max. } \\
\text { age }\end{array}$ \\
\hline \multirow[t]{2}{*}{ Colonization stage } & Initial phase (IP) & 0 & 1 & 0 & 2 & 0 & 0 \\
\hline & Pioneer phase (PP) & 2 & 2 & 2 & 5 & 1 & 1 \\
\hline \multicolumn{8}{|c|}{ - Reed succession line } \\
\hline \multirow[t]{2}{*}{ Transitional stage } & Herb reed phase $\left(\mathrm{HP}^{\star}\right)$ & 3 & 7 & - & - & 2 & 3 \\
\hline & Shrub reed phase $\left(\mathrm{SP}^{\star}\right)$ & - & - & - & - & 4 & 10 \\
\hline \multicolumn{8}{|c|}{ - Wetland succession line } \\
\hline \multirow[t]{3}{*}{ Transitional stage } & Deep oxbow phase (DO) & 3 & 30 & - & - & - & - \\
\hline & Shallow oxbow phase (SO) & 30 & 50 & - & - & - & - \\
\hline & Bog forest phase (BF) & 50 & 100 & - & - & - & - \\
\hline \multicolumn{8}{|c|}{ - Woodland succession line } \\
\hline \multirow[t]{4}{*}{ Transitional stage } & $\begin{array}{l}\text { Pioneer shrub phase (PS) / } \\
\text { Herb woodland phase (HP) }\end{array}$ & 3 & 3 & - & - & 2 & 4 \\
\hline & Shrub phase (SP) & 4 & 10 & - & - & 5 & 10 \\
\hline & $\begin{array}{l}\text { Early successional woodland } \\
\text { phase (ES) }\end{array}$ & 10 & 60 & 5 & 16 & 11 & 15 \\
\hline & $\begin{array}{l}\text { Established forest woodland } \\
\text { phase (EF) }\end{array}$ & 60 & 150 & 16 & 49 & 16 & 20 \\
\hline Mature stage & $\begin{array}{l}\text { Mature mixed forest phase } \\
\text { (MF) }\end{array}$ & - & - & 49 & 100 & 21 & 44 \\
\hline
\end{tabular}

The succession-retrogression scheme for the Kleblach reach (Figure 4) represents both the succession pathways observed in field, within a succession series or between series, and the possible retrogressions due to shear stress impacts. The IP and the PP were defined as common phases for the different succession series. While reed series can progress to the woodland series after $\mathrm{HP}^{*}$, becoming SP, the wetland series conforms a complete succession series itself. On the other hand, if shear stress impacts occur, the succession series 
will start over from the beginning, no matter which succession line, stage of evolution, or succession phase is present.

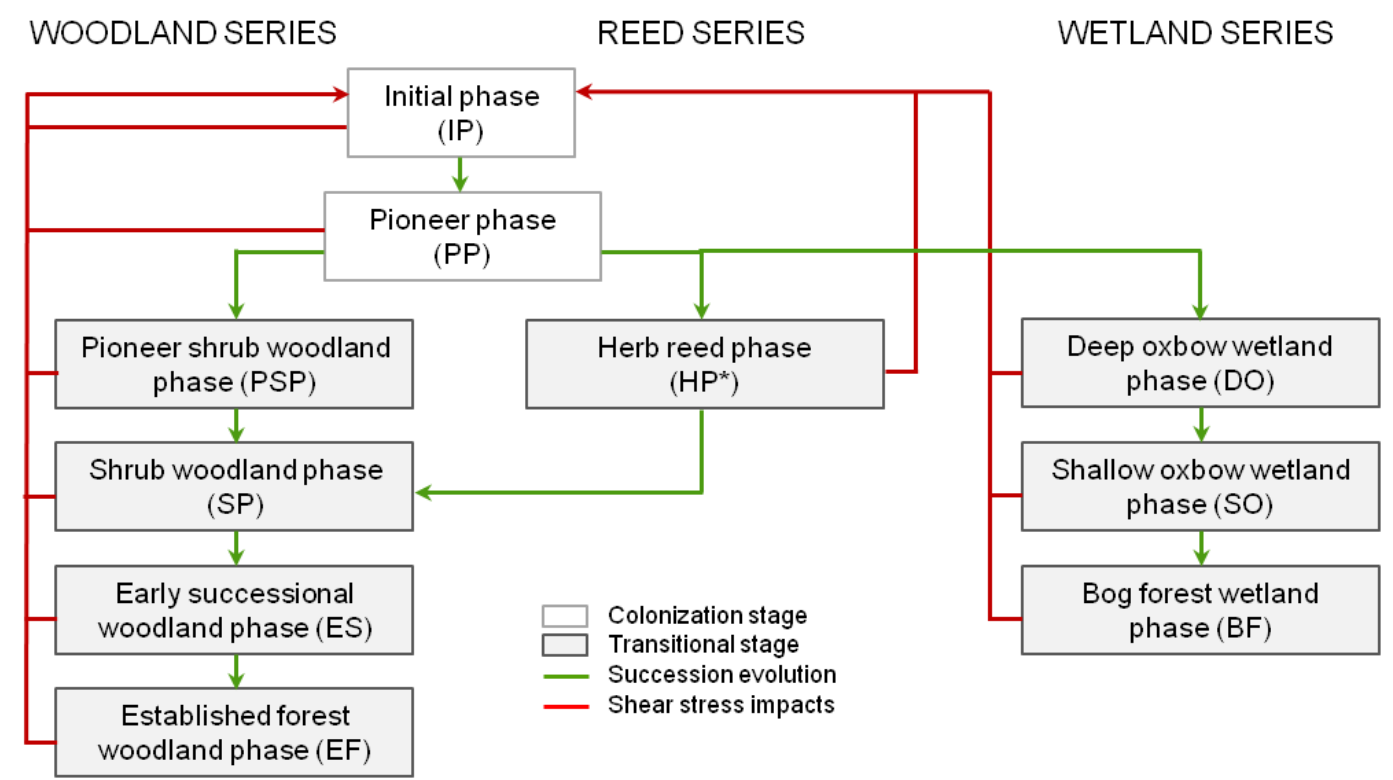

Figure 4. Scheme of the succession-retrogression pathways for the vegetation phases in the Kleblach reach (Drau River, Austria).

Model inputs for the Ribeira reach study site.

For the Ribeira reach (Odelouca River, Portugal), available flow data series included daily flows between 1962 and 2009 (Figure 5). These data came from the Monte dos Pachecos gauging station, that covers a draining basin area of $386 \mathrm{~km}^{2}$ and is located near and downstream of the study site. The morphology of the reach was considered stationary in terms of topography and riverine influence zones. The $A Z$ was defined as the area submerged by the base flow; indeed, since the river dries during summer, this zone was considered as the remaining pools when the flow is null. BZ and FPZ were defined as the areas submerged by the regular and 100 year return period discharges, respectively. Hydraulic modelling was performed using the River2D model software (Steffler et al., 2003) version 0.93. The channel roughness was defined by vegetation patch and according to the existent literature (adapted from Fisher and Dawson, 2003; Boavida, 2007; Wu and Mao, 2007).

In this Mediterranean semi-arid study site (also in the Spanish site), the flow regime has a torrential component. Hence, the maximum instantaneous flows were considered more appropriate in the establishment of high flood discharge classes in order to represent more realistic SS impacts over the vegetation. The WTE of the base flow was assigned to each year through classification by type of hydrological year. Twelve discharge classes, from the base flow to a $483 \mathrm{~m}^{3} / \mathrm{s}$ flow, were modeled in order to obtain water surface elevation maps and velocities. The WTE and SS maps were estimated from the subsequent results. 


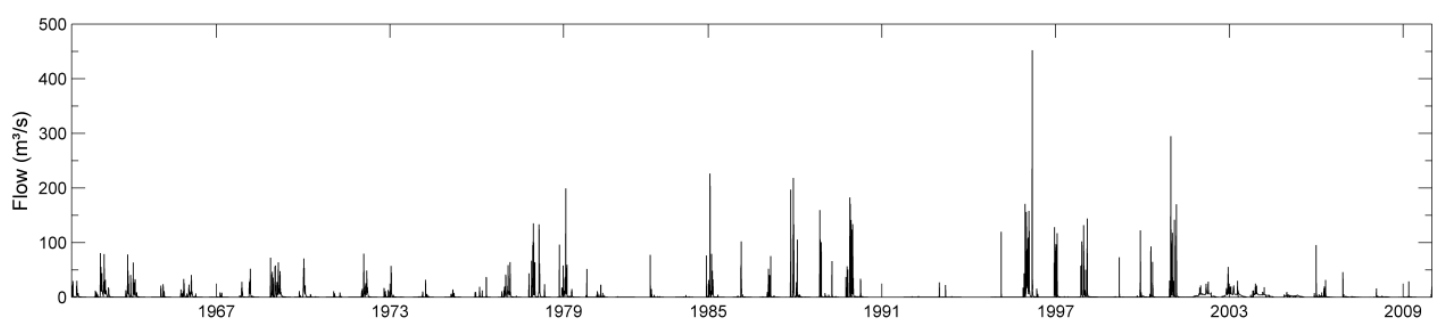

Figure 5. Daily river discharges $\left(\mathrm{m}^{3} / \mathrm{s}\right)$ in the Ribeira reach (Odelouca River, Portugal). Period: 1962-2009.

The vegetation survey was carried out at the Ribeira reach in summer 2009. Five succession phases were identified within the woodland series, as those were the ones distinguishable in terms of patch height above the base water level and age. SP and ES phases were gathered in the ES, because the ecological conditions did not allow a clear separation of these two phases in the vegetation. In this phase, the dominant pioneer species were willows, such as salvia-leaf willow (Salix salviifolia Brot.) and tamarisks (Tamarix africana Poir.). Older patches presenting high canopy cover were dominated by ash-trees (Fraxinus angustifolia Vahl.), considered as EF. The patches of MF were dominated by the ash, in mixed stands with terrestrial trees like cork oak (Quercus suber L.) or holm oak (Quercus ilex L. subsp. ballota). The age spans of the succession phases in each series are detailed in Table 1. Since no patches in the reed or wetland series were observed, the successionretrogression rules for this study site were fairly simple (Figure 6). As can be seen, exceeded critical shear stress is considered to sweep away the existing vegetation for all succession phases, so the succession starts over again from the first phase (IP) in the colonization stage.

WOODLAND SERIES

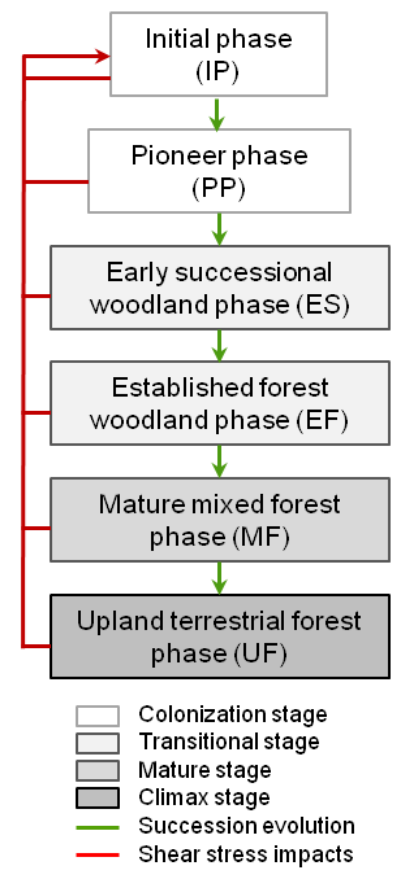

Figure 6. Scheme of the succession-retrogression pathways for the vegetation phases in the Ribeira reach (Odelouca River, Portugal). 
Model inputs for the Terde reach study site.

In the Terde reach (Mijares River, Spain), the flow data series corresponded to daily flows between the years 1969 and 2009 (Figure 7). These data came from the gauging station of the Mijares in Terde, which covers a draining basin area of $665 \mathrm{~km}^{2}$ and is located very near of the study site. The morphology of the reach was considered stationary in terms of topography and riverine influence zones. The AZ corresponded to the river channel area under the base flow for the driest conditions $\left(0.2 \mathrm{~m}^{3} / \mathrm{s}\right)$. BZ was defined as the wetted area in a regular discharge of $5 \mathrm{~m}^{3} / \mathrm{s}$ and $\mathrm{FPZ}$ as approximately the area covered by the 100 year return period discharge.

The influence zones, WTE and SS, were obtained by performing 2D hydraulic simulations with the Guad-2D software, which consists of a finite volume based two-dimensional model for the numerical simulation of transient flows over irregular topography, under the shallow water equations hypothesis (Murillo et al., 2008). Besides the DEM, a Manning roughness shape was defined as input according to Cowan estimation procedure, considering both grain size and vegetation features along the reach. Twenty discharge classes from the base flow to a $650 \mathrm{~m}^{3} / \mathrm{s}$ flow were modeled to obtain the water surface elevations and the velocities associated to each of those discharge classes. These results were used to obtain the WTE maps and the SS maps as explained in the general description of the hydrological inputs definition.

The WTE of the base flow was assigned to each year through classification by type of hydrological year, being these base flow discharge categories $1 \mathrm{~m} / \mathrm{s}$ for very wet years, $0.5 \mathrm{~m} \mathrm{~m}^{3} / \mathrm{s}$ for wet and medium years, and $0.2 \mathrm{~m}^{3} / \mathrm{s}$ for dry and very dry years. As justified in the inputs description of the Portuguese study site, maximum instantaneous peak flows (between 2.5 and $650 \mathrm{~m}^{3} / \mathrm{s}$ ) were considered to represent more realistic SS impacts on the vegetation.

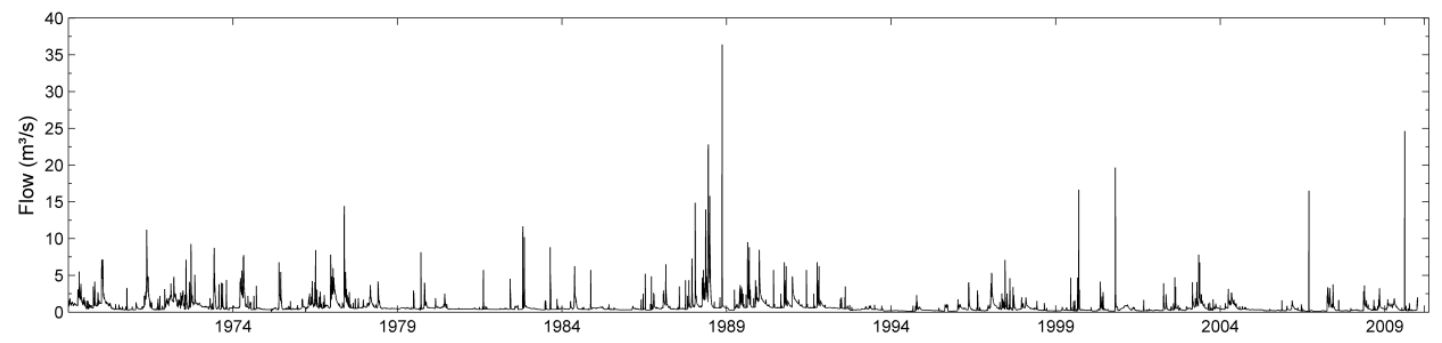

Figure 7. Daily river discharges $\left(\mathrm{m}^{3} / \mathrm{s}\right)$ in the Terde reach (Mijares River, Spain). Period: 19692009.

The vegetation survey was carried out in Terde once 2009 ended. Two parallel and interconnected succession series were identified in the site: woodland (dominated by willows and poplars) and reed (dominated by common reed). The age spans of the succession phases in each series are detailed in Table 1. The IP and the PP were defined as common phases for both series (Figure 8), in which the recruitment of early successional species occurs, as rosemary willow (Salix elaeagnos Scop.), purple willow (Salix purpurea L.), white willow (Salix alba L.), black poplar (Populus nigra L.) or common reed (Phragmites australis (Cav.) Trin. ex Steud.). After this colonization stage, both series take different paths during the transition stage. In both succession series, the herb phases (HP and $\mathrm{HP}^{*}$ ) are followed by their respective shrub phases (SP and $\left.\mathrm{SP}^{\star}\right)$. In the transition stage, the ES and EF are dominated by rosemary willow, 
purple willow and black poplar. Finally, under stable conditions, the riparian and terrestrial species, such as juniper (Juniperus spp.), kermes oak (Quercus coccifera L.) and holm oak (Quercus ilex L. subsp. ballota) dominate together in the MF. The general succession-retrogression diagram was based on the premise that the shear stress during flood events produces the complete removal of the non-resistant vegetation (scheme in Figure 8).

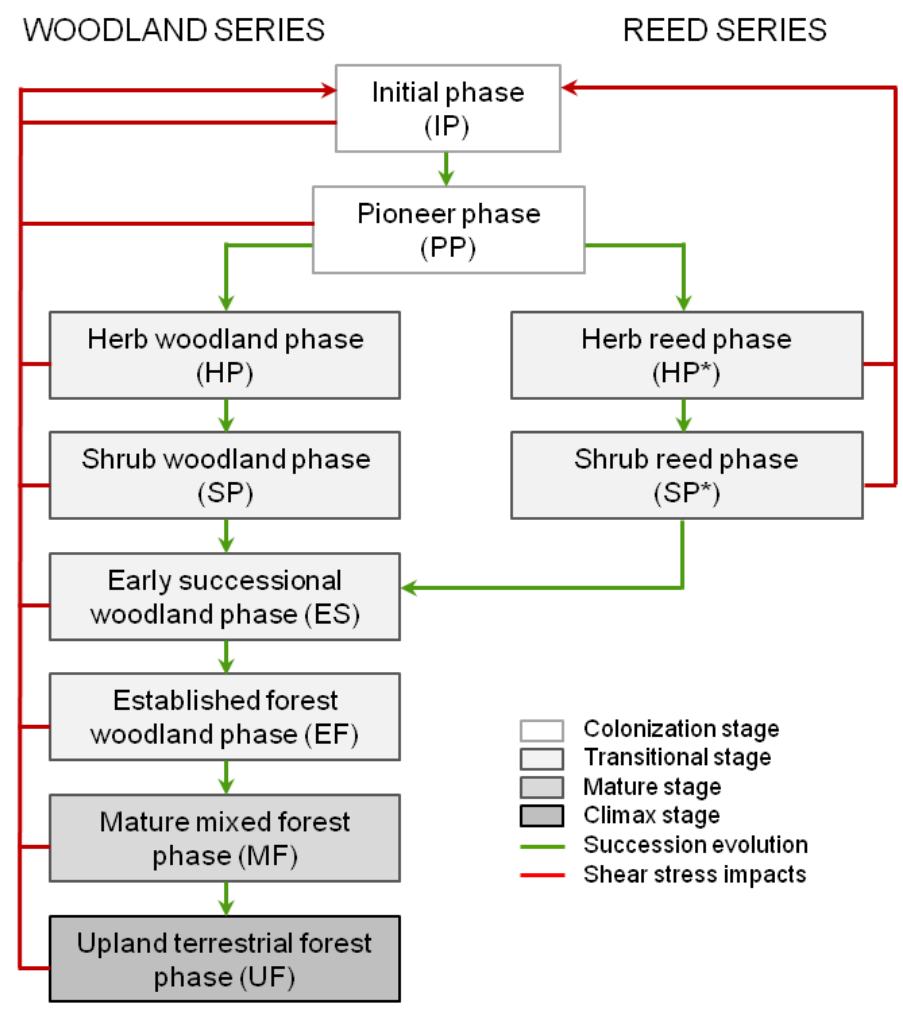

Figure 8. Scheme of the succession-retrogression pathways for the vegetation phases in the Terde reach (Mijares River, Spain).

\section{MODEL CALIBRATION AND VALIDATION STRATEGY}

In any mathematical model simulation, the establishment of an initial condition of the state variables is needed. In CASiMiR-vegetation model this corresponds to an initial vegetation map. In the Kleblach reach (Drau River, Austria) the initial condition corresponded to the observed vegetation in the first months of 2003, just after the geomorphological restoration of the stream accomplished in that site. Thus, the initial condition was assumed as the observed vegetation once 2002 ended. In this study site, some additional observed vegetation maps were available for the years 2005 and 2007-2010, consecutively. In the Ribeira reach (Odelouca River, Portugal), the available maps for comparison issues were 1995 and 2009. Two periods of eleven years were considered sufficient for calibration and validation purposes, so initial conditions corresponding to the vegetation map in 1984 and in 1998 were obtained through the start condition module proposed by Benjankar et al. (2011). Finally, in the Terde reach (Mijares River, Spain), four vegetation maps were available. The first one and more reliable corresponded to the observed vegetation in field once 2009 ended. Two other maps were obtained from aerial photographs and expert knowledge for 
the years 1985 and 2000. The last one was estimated considering the maximum instantaneous flow in the data series. A huge flood $\left(650 \mathrm{~m}^{3} / \mathrm{s}\right)$ that occurred during 1968 and it was supposed to remove mostly all the vegetation from the riparian bands on its way. This assumption was proven to be coherent after the model was calibrated. Including this map as the initial vegetation, both for calibration and validation issues, a non-dependence on the starting condition was achieved.

The calibration of CASiMiR-vegetation model was made by expertise trial and error of the parameters of sub-models, comparing simulated and observed end of period vegetation maps. The model was calibrated considering a time period of 8 years (2003-2010) in the Kleblach reach (Drau River, Austria), 11 years (1999-2009) in the Ribeira reach (Odelouca River, Portugal), and 41 years (1969-2009) in the Terde reach (Mijares River Spain). The differences between the reaches were considered important in terms of their hydrological and biological characteristics. Consequently, the model was calibrated independently for each specific study site.

The model was validated temporally in each study site. The validation of the model in the Kleblach reach (Drau River, Austria) was analyzed in 2003, 2005, 2007, 2008 and 2009 vegetation maps, considering the same initial condition as for the calibration. In the Ribeira reach (Odelouca River, Portugal), a unique period of 11 years (1985-1995) was analyzed comparing the observed and simulated vegetation maps of 1995 . The last case study, the Terde reach (Mijares River, Spain), allowed a validation of the model in two different years within the calibration period (1985 and 2000 vegetation maps) corresponding to periods of 17 and 32 years respectively.

\section{Objective functions}

Although some details in the calibration and validation approaches were different in order to encompass the specificities of each site data, the performance evaluation for all the cases tackled a common strategy in order to make results comparable. In the three cases, we calculated the confusion matrix resultant of the comparison between the observed and the simulated vegetation maps. Three criteria were considered to evaluate the quality of the simulated distribution of every vegetation succession phases: the correctly classified instances $(\mathrm{CCl})$, the kappa $(k)$ coefficient of agreement (Cohen, $1960)$, and the weighted kappa $\left(k^{\star}\right)$ coefficient (Cohen, 1968).

$$
\begin{aligned}
& C C I=\frac{1}{N} \sum_{i=1}^{n} X_{i i} ; \quad k=\frac{f_{0}-f_{e}}{1-f_{e}} ; \quad k^{*}=\frac{f_{0}(w)-f_{e}(w)}{1-f_{e}(w)} ; \\
& f_{0}(w)=\frac{1}{N} \sum_{i=1}^{n} \sum_{j=1}^{n} W_{i j} X_{i j} ; \quad f_{e}(w)=\frac{1}{N^{2}} \sum_{i=1}^{n} \sum_{j=1}^{n} W_{i j} r_{i} C_{j}
\end{aligned}
$$

where, $N$ : total number of cells; $n$ : total number of phases; $x_{i i}$ : total number of cells correctly simulated for each phase; $f_{o}$ : relative observed agreement among maps; $f_{\mathrm{e}}$ : hypothetical relative agreement expected by chance; $w_{i j}$ : element in the weights matrix which are 0 (on the main diagonal) and (distance from diagonal) $)^{2}$ in the other cells; $r_{i}$ : row total for each phase in the confusion matrix; $c_{j}$ : column total for each phase in the confusion matrix. These three criteria 
$\left(\mathrm{CCl}, k\right.$, and $\left.k^{*}\right)$ have 1 as maximum value when agreement between the predictions and the observations is perfect.

Additionally, the model performance for each stage of development was estimated, i.e., the criteria described above were calculated separately for three categories (colonization stage, transition stage and mature-climax stages). Also, other criteria were analysed based on the presence/absence confusion matrix of the succession stages. Thus, the accuracy of each development stage modelling was estimated through: the area under the receiver operating characteristic (ROC) curve, known as the $A U C$, and calculated using a MannWhitney $U$ statistic; the correctly predicted positive fraction or sensitivity; the correctly predicted negative fraction or specificity; the falsely predicted negative fraction or omission rate; the falsely predicted positive fraction or commission rate; and the proportion of the presence and absence records correctly identified, named accuracy $(A C C)$. These statistics are defined as follows:

$$
\begin{aligned}
& \text { AUC }=\frac{U}{(b+c) \cdot(a+d)} ; \quad \text { Sensitivity }=\frac{a}{a+d} ; \quad \text { Specificity }=\frac{b}{b+c} ; \\
& \text { Omission rate }=\frac{d}{b+d} ; \quad \text { Commission rate }=\frac{c}{a+c} ; \quad \text { ACC }=\frac{a+b}{N}
\end{aligned}
$$

where, $U$ : Mann-Whitney $U$ statistic; a: total number of true positive simulated cells (presence is observed and predicted); $b$ : total number of true negative simulated cells (absence is observed and predicted); $c$ : total number of false positive simulated cells (presence is predicted but not observed); $d$ : total number of false negative simulated cells (presence is observed but not predicted).

\section{CALIBRATION RESULTS}

The model was finally calibrated in the three selected study sites with the parameter values shown in Table 2. As it was explained before, the differences among the succession phases, among species, and the presence of different succession lines required to set the specific parameters for each reach. Since the recruitment sub-model determines the vegetation recruitment in terms of height above the base/mean water level, different influence areas were set for each possible succession series. The limitations to the vegetation recruitment in the reaches came from two different sources: the constraint of the available areas for recruitment to some limited height ranges (i.e. the Portuguese case study); and the establishment of scour disturbances large enough to impact on the seedlings establishment (i.e. the Spanish case study).

Critical shear stress parameters were set higher for those riparian phases capable to resist harder impacts. Plants with fine roots have high tensile strength (De Baets et al., 2008). Nevertheless, although their roots are usually thin, not all the species included in phases typically characterized by herbs and shrubs have high resistance. Since reed species as Phragmites australis have been reported to be more resistant than non-reed species (De Baets et al., 2008), the critical values have been set higher for $\mathrm{HP}^{*}$ and $\mathrm{SP}^{*}$ than for HP, SP and PSP. Finally, some common riparian tree species have been reported to 
resist pull-out forces of averaged values close to $400 \mathrm{~N} / \mathrm{m}^{2}$ (Karrenberg et al., 2003; Stokes et al., 2009). The shear resistances have been set in the same order of magnitude for the riparian tree phases.

Table 2. Model calibrated parameters.

\begin{tabular}{|c|c|c|c|}
\hline Parameter & $\begin{array}{l}\text { Kleblach reach } \\
\text { (Drau River, } \\
\text { Austria) }\end{array}$ & $\begin{array}{l}\text { Ribeira reach } \\
\text { (Odelouca River, } \\
\text { Portugal) }\end{array}$ & $\begin{array}{l}\text { Terde reach } \\
\text { (Mijares } \\
\text { River, Spain) }\end{array}$ \\
\hline $\mathrm{HBWL}^{(1)} / \mathrm{HMWL}^{(2)}$ for Reed Recruitment in the $\mathrm{BZ}(\mathrm{m})$ & $>0.5$ & - & $>0.47$ \\
\hline $\mathrm{HBWL}^{(1)} / \mathrm{HMWL}^{(2)}$ for Reed Recruitment in the FPZ $(\mathrm{m})$ & $>0.8$ & - & $<1.2$ \\
\hline $\mathrm{HBWL}^{(1)} / \mathrm{HMWL}^{(2)}$ for Woodland Recruitment in the BZ $(\mathrm{m})$ & $<0.5$ & $0.36-2.78$ & $<0.47$ \\
\hline $\mathrm{HBWL}^{(1)} / \mathrm{HMWL}^{(2)}$ for Woodland Recruitment in the FPZ $(\mathrm{m})$ & $<0.8$ & $0.36-2.78$ & $>1.2$ \\
\hline $\mathrm{HBWL}^{(1)} / \mathrm{HMWL}^{(2)}$ for Wetland Recruitment in the FPZ $(\mathrm{m})$ & $<0.8$ & - & - \\
\hline $\mathrm{HBWL}^{(1)} / \mathrm{HMWL}^{(2)}$ for Scour Disturbance Zone & - & $<0.36$ & $<0.75$ \\
\hline \multirow[t]{2}{*}{ Critical Shear Stress of colonization stage phases $\left(\mathrm{N} / \mathrm{m}^{2}\right)$} & $1(\mathrm{IP})$ & $30(\mathrm{IP})$ & $10(\mathrm{IP})$ \\
\hline & $3(\mathrm{PP})$ & $30(\mathrm{PP})$ & $60(\mathrm{PP})$ \\
\hline \multirow[t]{6}{*}{ Critical Shear Stress of Woodland $\left(\mathrm{N} / \mathrm{m}^{2}\right)$} & 25 (PSP) & 50 (ES) & $70(\mathrm{HP})$ \\
\hline & $60(\mathrm{SP})$ & $300(\mathrm{EF})$ & $90(\mathrm{SP})$ \\
\hline & 400 (ES) & 300 (MF) & $140(E S)$ \\
\hline & $400(E F)$ & & $200(E F)$ \\
\hline & & & 65 (MF) \\
\hline & & & 300 (UF) \\
\hline \multirow[t]{2}{*}{ Critical Shear Stress of Reed $\left(\mathrm{N} / \mathrm{m}^{2}\right)$} & $40\left(\mathrm{HP}^{\star}\right)$ & - & $150\left(\mathrm{HP}^{\star}\right)$ \\
\hline & & & $150\left(\mathrm{SP}^{*}\right)$ \\
\hline \multirow[t]{3}{*}{ Critical Shear Stress of Wetland $\left(\mathrm{N} / \mathrm{m}^{2}\right)$} & 25 (DO) & - & - \\
\hline & 35 (SO) & & \\
\hline & 40 (BF) & & \\
\hline
\end{tabular}

${ }^{(1)}$ Height above the base water level; ${ }^{(2)}$ Height above the mean water level

The results showed enough variability through the calibration periods, to be considered realistic. During flood events, important areas of the riparian vegetation zones were removed by the model in every case study. Ending the calibration period, the model succeeded in the general pattern of the distribution of vegetation phases (Figure 9).

The good calibration results achieved (Table 3 ) demonstrated that a high-quality calibration process allows the model to reproduce correctly the fluvial dynamics exerted on riparian patches and its resilience response with an adequate quality.

The first type of confusion matrix, with comparison phase to phase, provided the correctly classified instances $(C C l)$, the kappa $(k)$ and the weighted kappa $\left(k^{\star}\right)$ values. The $\mathrm{CCl}$ results obtained values between 0.52 and 0.62 in every case study, once the model was considered calibrated. The $k^{\star}$ values showed considerably increases of the agreement in every study site compared to the $k$ results. These values (in the 0.52-0.66 range) were very satisfying, especially taking into account the high number of possible categories to be simulated. 


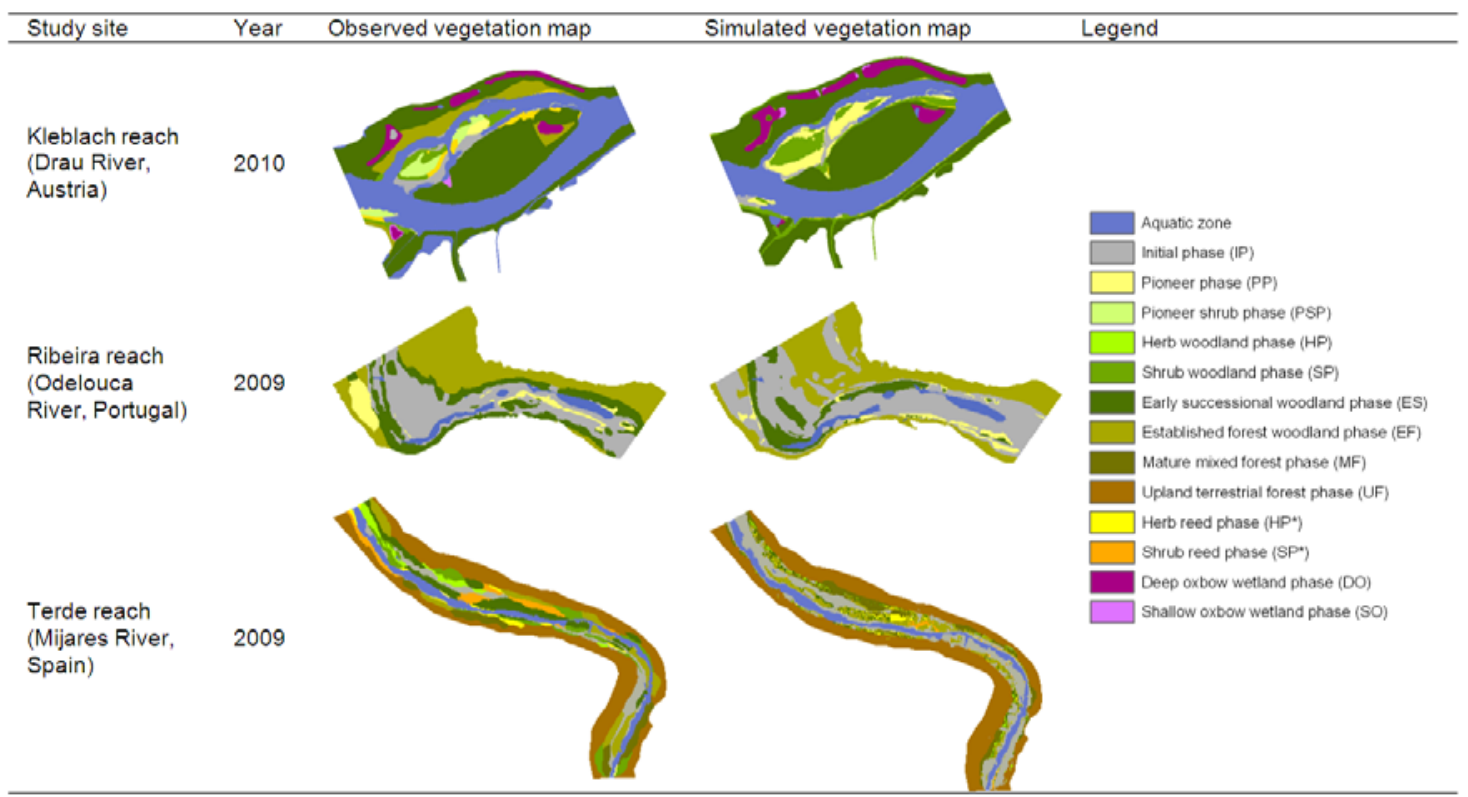

Figure 9. Observed and simulated vegetation maps for the ending year of the calibration periods in the three case studies.

Table 3. Indices of calibration performance in the three case studies.

\begin{tabular}{|c|c|c|c|c|}
\hline $\begin{array}{l}\text { Type of } \\
\text { Classification }\end{array}$ & Statistic & $\begin{array}{l}\text { Kleblach reach (Drau } \\
\text { River, Austria) Year } \\
2010\end{array}$ & $\begin{array}{l}\text { Ribeira reach } \\
\text { (Odelouca River, } \\
\text { Portugal) Year } 2009\end{array}$ & $\begin{array}{l}\text { Terde reach (Mijares } \\
\text { River, Spain) Year } \\
2009\end{array}$ \\
\hline \multicolumn{5}{|l|}{ Phases } \\
\hline & $\mathrm{CCl}$ & 0.624 & 0.578 & 0.523 \\
\hline & Kappa & 0.324 & 0.377 & 0.337 \\
\hline & Weighted kappa & 0.657 & 0.528 & 0.521 \\
\hline \multicolumn{5}{|l|}{ Stages } \\
\hline & $\mathrm{CCl}$ & 0.938 & 0.697 & 0.655 \\
\hline & Kappa & 0.545 & 0.402 & 0.425 \\
\hline \multicolumn{5}{|c|}{$\begin{array}{l}\text { Weighted kappa } \\
\text { AUC }\end{array}$} \\
\hline & Colonization stage & 0.600 & 0.888 & 0.524 \\
\hline & Transitional stage & 0.600 & 0.829 & 0.758 \\
\hline & $\begin{array}{l}\text { Mature \& climax } \\
\text { stages }\end{array}$ & - & 0.502 & 0.752 \\
\hline \multicolumn{5}{|c|}{$\begin{array}{l}\text { Slages } \\
\text { Sensitivity }\end{array}$} \\
\hline & Colonization stage & 0.755 & 0.777 & 0.612 \\
\hline & Transitional stage & 0.950 & 0.657 & 0.336 \\
\hline & $\begin{array}{l}\text { Mature \& climax } \\
\text { stages }\end{array}$ & - & 0.004 & 0.894 \\
\hline \multicolumn{5}{|c|}{ Specificity } \\
\hline & Colonization stage & 0.051 & 1.000 & 0.340 \\
\hline & Transitional stage & 0.245 & 1.000 & 0.149 \\
\hline & $\begin{array}{l}\text { Mature \& climax } \\
\text { stages }\end{array}$ & - & 1.000 & 0.610 \\
\hline \multicolumn{5}{|c|}{$\begin{array}{l}\text { Stages } \\
\text { Omission rate }\end{array}$} \\
\hline & Colonization stage & 0.220 & 0.122 & 0.105 \\
\hline & Transitional stage & 0.780 & 0.346 & 0.732 \\
\hline & $\begin{array}{l}\text { Mature \& climax } \\
\text { stages }\end{array}$ & - & 0.009 & 0.163 \\
\hline \multicolumn{5}{|c|}{$\begin{array}{c}\text { stages } \\
\text { Commission rate }\end{array}$} \\
\hline & Colonization stage & 0.955 & 0.000 & 0.913 \\
\hline & Transitional stage & 0.045 & 0.000 & 0.805 \\
\hline & $\begin{array}{l}\text { Mature \& climax } \\
\text { stages }\end{array}$ & - & 0.000 & 0.282 \\
\hline \multicolumn{5}{|c|}{ ACc ${ }^{\text {stages }}$} \\
\hline & Colonization stage & 0.090 & 0.914 & 0.366 \\
\hline & Transitional stage & 0.909 & 0.792 & 0.220 \\
\hline & $\begin{array}{l}\text { Mature \& climax } \\
\text { stages }\end{array}$ & - & 0.991 & 0.759 \\
\hline
\end{tabular}


The $C C l$, the $k$ and the $k^{*}$ values were calculated additionally in terms of stages absence/presence in order to make results comparable with those previously obtained for the phases classification (Table 3). These coefficients improved when the classification was based on succession stages. The $\mathrm{CCl}$ values increased to values between 0.66 and 0.94 , which represented an increase from $12 \%$ to $32 \%$ of correctly simulated cells. The $k$ values were better, up to an increase of 0.23 in the Austrian case study. Values between 0.5 and 0.89 in terms of AUC, and high values of sensitivity and of ACC (higher than 0.75 in most of the cases) completed the calibration performance analysis.

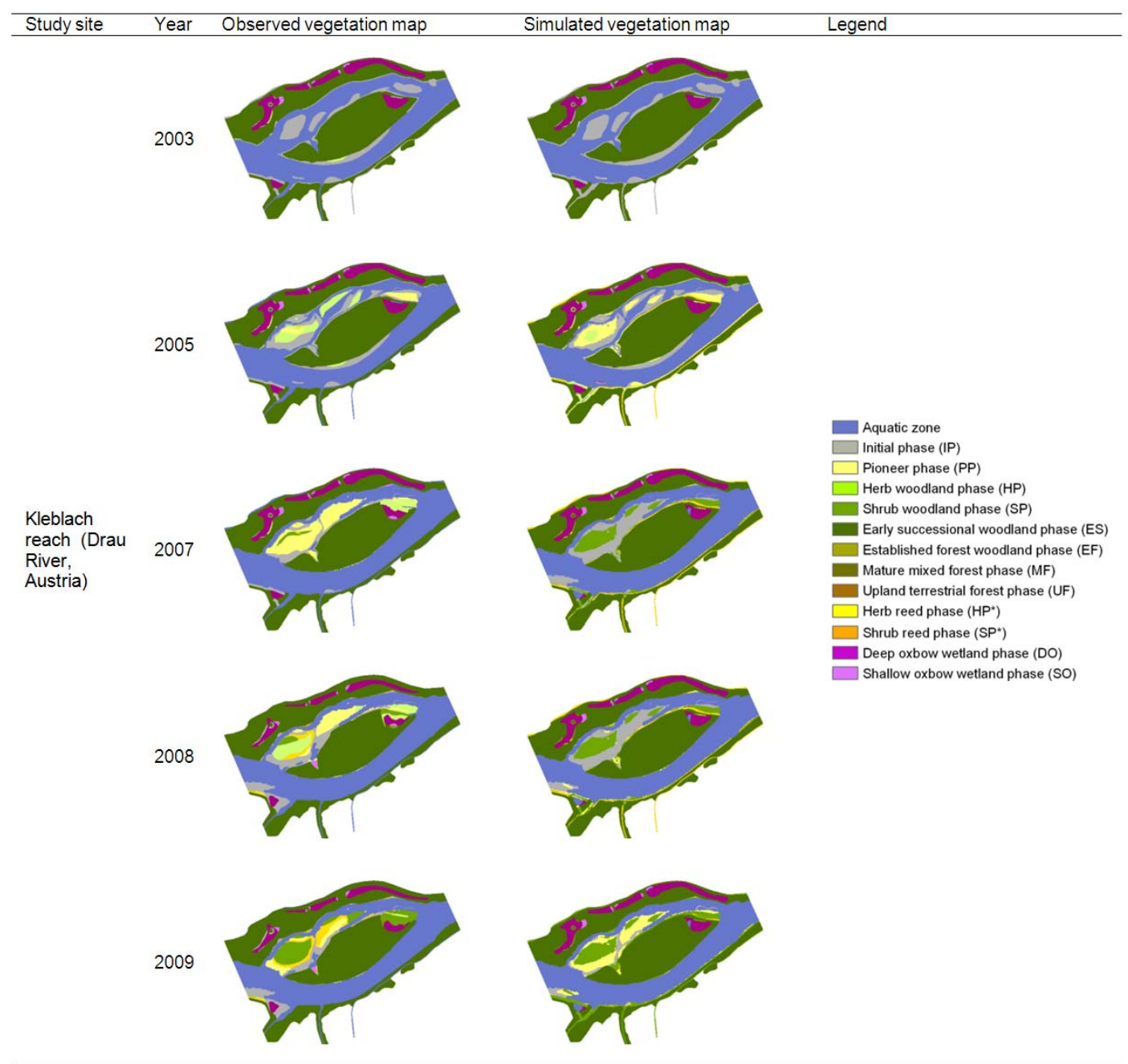

Figure 10. Observed and simulated vegetation maps for the validation period in the Kleblach reach (Drau River, Austria).

\section{VALIDATION RESULTS}

Similar results, or better in some cases, were obtained in the temporal validation analysis. The results are presented in two different tables, although the structure is the same as in the calibration section. The Kleblach reach validation analysis comprised five years between 2003 and 2009 results (Figure 10). 
The availability of observed vegetation maps in sequence allowed the analysis of the results evolution in time. It can be summarized as follows: the closer to the initial condition, the better results obtained in the majority of the performance indices. The differences in time were generally lower in the classification by stage than by phase, as expected. Nevertheless, both the stages and the phases classifications performed in very good ranges in the complete set of maps used in the model validation

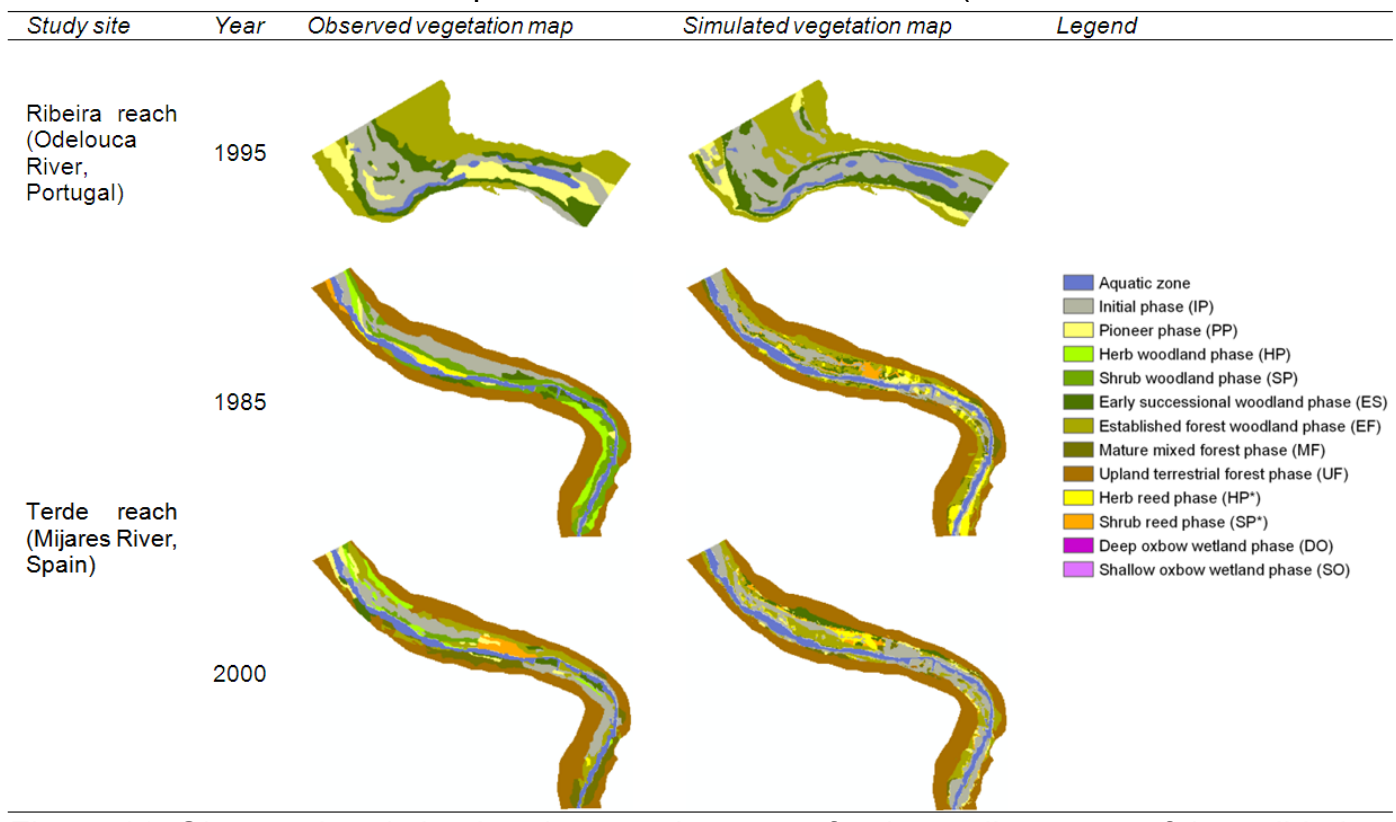

Figure 11. Observed and simulated vegetation maps for the ending years of the validation periods in the Ribeira reach (Odelouca River, Portugal) and in the Terde reach (Mijares River, Spain).

). These results, especially the high values of $\mathrm{CCl}(>0.65$ in phases classification and $>0.91$ in stages classification), $k$ ( $>0.38$ and $>0.52$, respectively), $k^{\star}(>0.64$ and $>0.52$, respectively), AUC (>0.5), sensitivity (> 0.58 ) and $A C C$ ( $>0.83$ for the transitional stage), indicated once more the robustness of the model in this Alpine climate.

Table 4. Indices of validation performance in the Kleblach reach (Drau River, Austria).

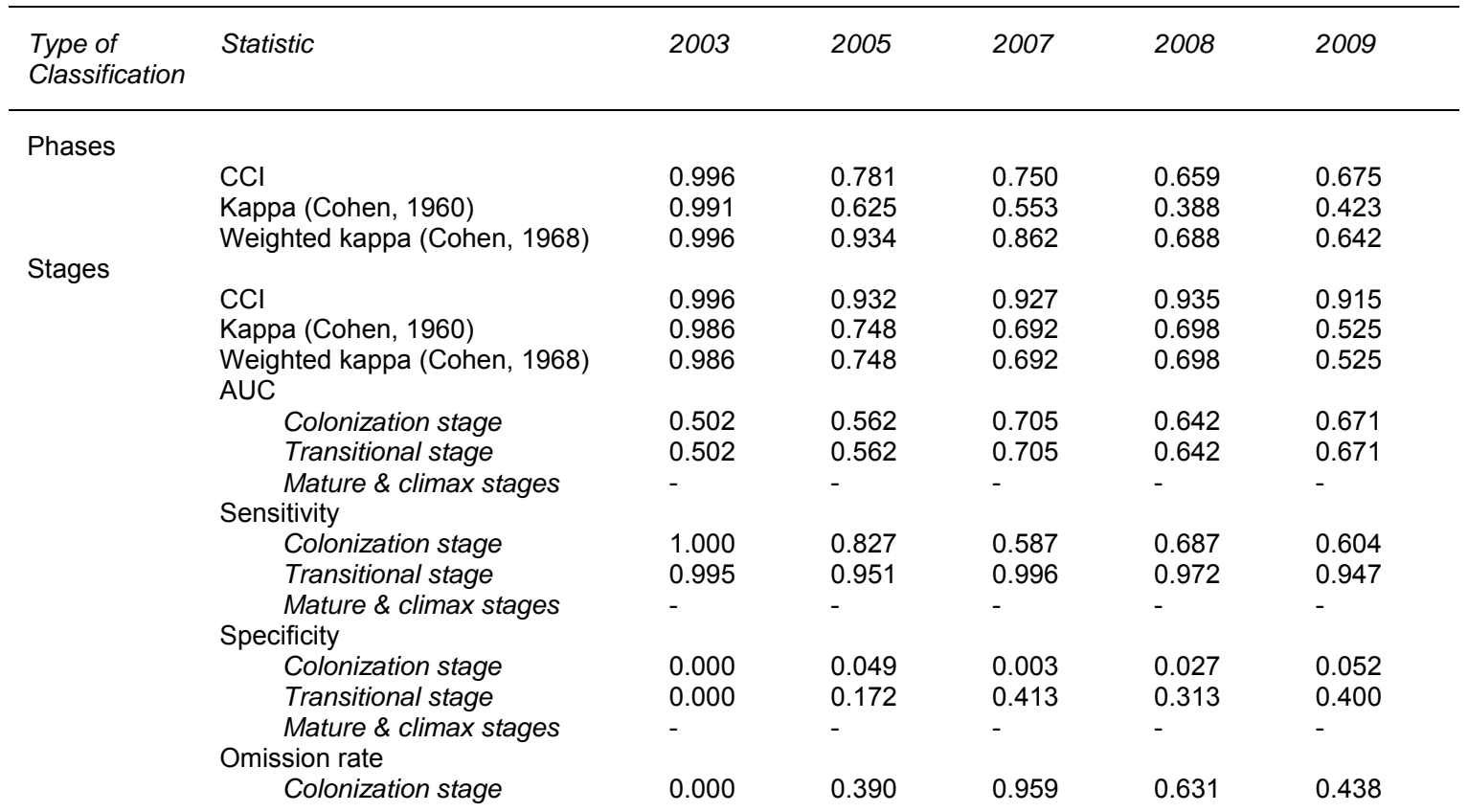




\begin{tabular}{|c|c|c|c|c|c|}
\hline Transitional stage & 0.160 & 0.610 & 0.041 & 0.368 & 0.562 \\
\hline Mature \& climax stages & - & - & - & - & - \\
\hline \multicolumn{6}{|l|}{ Commission rate } \\
\hline Colonization stage & 0.840 & 0.864 & 0.893 & 0.903 & 0.938 \\
\hline Transitional stage & 0.161 & 0.136 & 0.107 & 0.096 & 0.062 \\
\hline Mature \& climax stages & - & - & - & - & - \\
\hline \multicolumn{6}{|l|}{ ACC } \\
\hline Colonization stage & 0.164 & 0.168 & 0.102 & 0.114 & 0.104 \\
\hline Transitional stage & 0.836 & 0.832 & 0.898 & 0.886 & 0.896 \\
\hline Mature \& climax stages & - & - & - & - & - \\
\hline
\end{tabular}

In the Mediterranean climate, the results (Figure 11, Table 5) were considerable good and homogeneous, not only between both Mediterranean case studies or between analysed periods, but also compared to the calibration performance. The results obtained were $\mathrm{CCl}(\approx 0.6$ in phases classification and $\approx 0.7$ in stages classification), $k$ ( $\approx 0.4$ and $>0.41$, respectively), $k^{*}$ (up to 0.6 and 0.82 , respectively), AUC (between 0.56 and 0.88), sensitivity (up to 0.999), an excellent specificity for the Portuguese case study, and reasonable good results of $A C C$ ( $\approx 0.8$ for advanced stages).

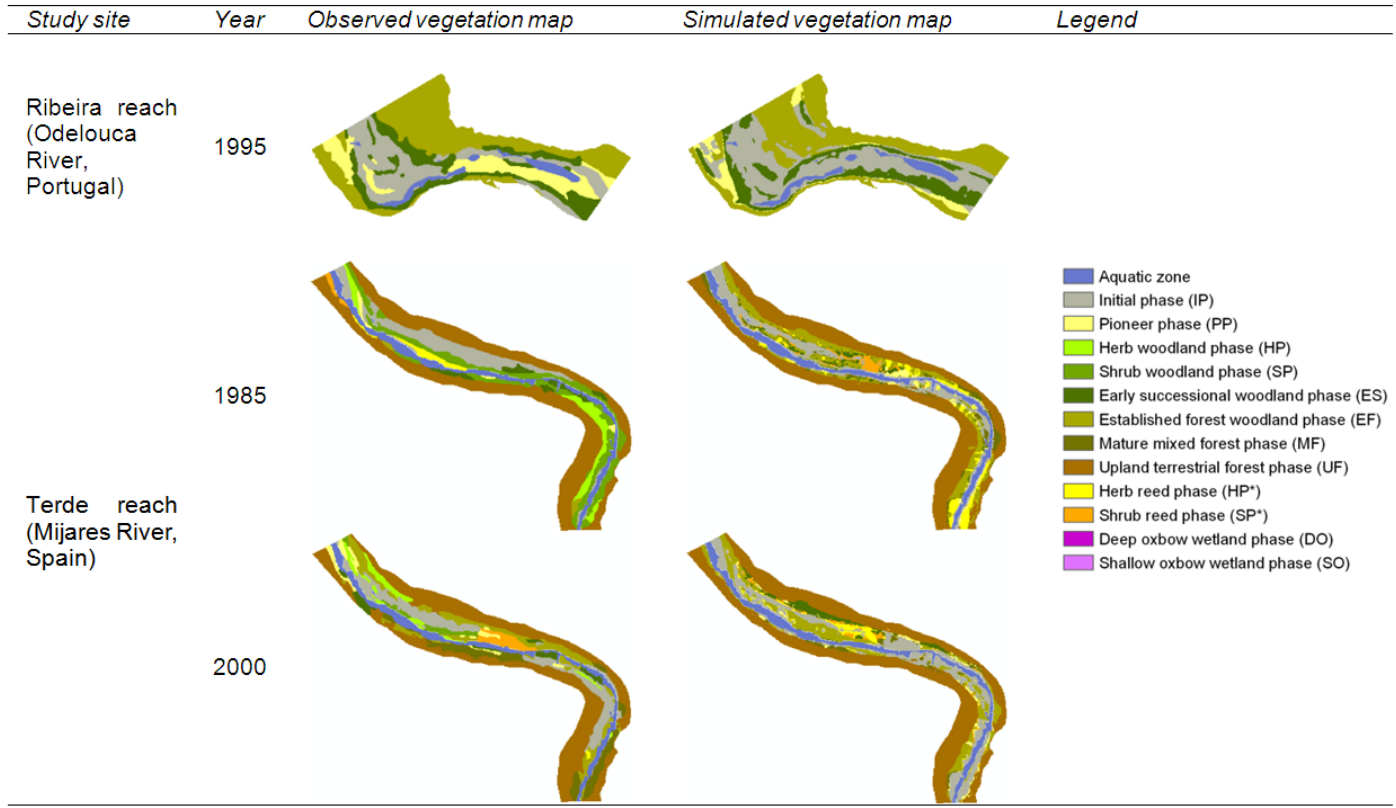

Figure 11. Observed and simulated vegetation maps for the ending years of the validation periods in the Ribeira reach (Odelouca River, Portugal) and in the Terde reach (Mijares River, Spain).

Table 5. Indices of validation performance in the Mediterranean study sites, the Ribeira reach (Odelouca River, Portugal) and the Terde reach (Mijares River, Spain).

\begin{tabular}{lllll}
\hline $\begin{array}{l}\text { Type of } \\
\text { Classification }\end{array}$ & Statistic & $\begin{array}{l}\text { Ribeira reach } \\
\text { (Odelouca River, } \\
\text { Portugal) Year 1995 }\end{array}$ & $\begin{array}{l}\text { Terde reach } \\
\text { (Mijares River, } \\
\text { Spain) Year 1985 }\end{array}$ & $\begin{array}{l}\text { Terde reach } \\
\text { (Mijares River, } \\
\text { Spain) Year 2000 }\end{array}$ \\
\hline Phases & & & & \\
& CCl & 0.569 & 0.583 & 0.545 \\
& Kappa & 0.391 & 0.407 & 0.368 \\
Stages & Weighted kappa & 0.556 & 0.648 & 0.566 \\
& CCl & 0.720 & 0.792 & 0.673 \\
& Kappa & 0.419 & 0.656 & 0.433 \\
& Weighted kappa & 0.419 & 0.816 & 0.557 \\
\hline
\end{tabular}




\begin{tabular}{|c|c|c|c|}
\hline \multicolumn{4}{|l|}{ AUC } \\
\hline Colonization stage & 0.835 & 0.717 & 0.563 \\
\hline Transitional stage & 0.877 & 0.616 & 0.759 \\
\hline Mature \& climax stages & - & 0.715 & 0.745 \\
\hline \multicolumn{4}{|l|}{ Sensitivity } \\
\hline Colonization stage & 0.669 & 0.423 & 0.569 \\
\hline Transitional stage & 0.753 & 0.636 & 0.298 \\
\hline Mature \& climax stages & - & 0.999 & 0.892 \\
\hline \multicolumn{4}{|l|}{ Specificity } \\
\hline Colonization stage & 1.000 & 0.142 & 0.305 \\
\hline Transitional stage & 1.000 & 0.132 & 0.185 \\
\hline Mature \& climax stages & - & 0.431 & 0.597 \\
\hline \multicolumn{4}{|l|}{ Omission rate } \\
\hline Colonization stage & 0.178 & 0.422 & 0.228 \\
\hline Transitional stage & 0.274 & 0.576 & 0.559 \\
\hline Mature \& climax stages & - & 0.002 & 0.183 \\
\hline \multicolumn{4}{|l|}{ Commission rate } \\
\hline Colonization stage & 0.000 & 0.919 & 0.854 \\
\hline Transitional stage & 0.000 & 0.735 & 0.879 \\
\hline Mature \& climax stages & - & 0.346 & 0.267 \\
\hline \multicolumn{4}{|l|}{ ACC } \\
\hline Colonization stage & 0.869 & 0.185 & 0.351 \\
\hline Transitional stage & 0.851 & 0.298 & 0.216 \\
\hline Mature \& climax stages & - & 0.726 & 0.760 \\
\hline
\end{tabular}

\section{DISCUSSION AND CONCLUSIONS}

Flow regime and patterns govern channel forms and determine the woody patches, including pioneer and recruitment areas, juvenile and adult stands and the interface with the terrestrial environment. Low flows and droughts determine the stands survival yearly; nevertheless, the stand mortality is mainly determined by the shear stress related to high flows. On the other hand, every river reach presents unique riparian structure according to the valley form and the channel topography and submersion periods. In this paper, we demonstrated that riparian processes are similarly ruled in different regions of Europe and, therefore, that riparian vegetation patches can be predicted regardless of the riparian configuration resulting from a specific climate or valley form. As such, riparian structure can be used as indicator of river functioning and as a tool in river management, e.g. for predicting the effects of humanrelated flow regime alteration, or the changes after restoration measures.

The dynamic floodplain vegetation model CASiMiR-vegetation was successfully implemented in three different sites, despite the differences found in vegetation community composition, hydrologic regimes and climatic conditions. Furthermore, the adopted modelling approach by succession phases overcame the vegetation species divergences between sites and could be used to create a systematic riparian characterization adaptable to European countries, or even worldwide, with a functional and dynamic perspective. The classification in succession phases was considered optimal for the transferability of results, because a species-to-species comparison is difficult, and these phases could be used to build the scheme of succession-retrogression pathways in any of the studied countries. Among the three countries, the succession phases showed differences in the types of dominant herbs or woody species in a patch, in the habitat conditions (abiotic factors such as soil texture, organic content, distance to the groundwater, etc.) and in the plant development stage (age).

The gathering of the input data with slightly different methodologies by each country was unavoidable. Nevertheless, the main guidelines were always followed. Two types of inputs related to the succession phases were necessary: 
observed vegetation maps and succession-retrogression schemes. A general classification in succession phases was followed in order to homogenize the typology in every study site. Nevertheless, some differences were necessarily introduced in each case study classification since not only different species but also different succession series were present in the study sites. Once the phases were defined in each study site, they could be grouped into three stages: colonization, transition and mature-climax stages, which were strictly common in all the analysed cases. The succession-retrogression schemes were built with two main guidelines: the colonization stage consisted of common phases for every series observed in a study site; and the retrogressions (shear stress impacts) were considered as vegetation removal, thus leading to bare soil (initial phase, IP).

When possible, the initial condition map corresponded to the observed vegetation in the initial year. Otherwise, the initial condition was created by the static component of the model, considering the topography, mean flow surface elevation and the information collected in the field regarding the age of the succession phases and their height above the base water level ranges (i.e. Portuguese case study).

In every case, the model calibration considered the performance observed in nature for the establishment of the parameters values. For example, critical shear stresses were set higher for those riparian phases capable to resist harder impacts. For each phase, it is assumed that the vegetation evolves if there are no disturbances (i.e. floods) great enough to induce retrogression. When vegetation reaches a certain age (considered as a threshold between two succession phases), the patch shifts to the next succession phase. Typically, older phases have deeper root systems and their survival strategy is based on resistance in detriment of a higher recovery rate. The contrary strategy behaves in most of the earlier phases, which have low resistance under stressing events, although they evolve very fast. Exceptionally, some riparian species (i.e. reed species) have typically high flexibility, since these plants are flood-resistant (De Baets et al., 2008; Glenz, 2005). The calibration parameters were comparable between study sites.

The model performance in calibration and validation was evaluated by several statistics. The indices $\mathrm{CCl}$, kappa and $A U C$ were considered to be the most used and best adequate criteria in this type of model evaluation (Mouton et al., 2010). Data from the calibration and validation maps were analyzed by comparison with the observed vegetation maps of the study sites. Confusion matrices were created from map comparison and its accuracy assessed by different methods. $\mathrm{CCl}$ was considered very helpful since it revealed the proportion of correctly classified pixels/cells of the maps. Cohen kappa $(k)$, which has a widespread use in ecological literature and represents the proportion of agreement corrected for chance between two judges assigning cases to a set of categories (Cohen, 1960), is considered to be a better measure than overall accuracy, because the percentage of agreement is corrected by the proportion of agreement achieved by random relocation of all cells in the maps (Hagen, 2002). Moreover, $k$ is not affected by the existence of zero values in the confusion matrix as it happens with similar techniques that also predict occurrence at better rates than chance expectation. This coefficient has been widely used in map comparison and is considered to provide a simple, effective, standardized and appropriate statistic to evaluate the agreement 
between two categorical data (Manel et al., 2001). However, because we worked in relatively ample geographical locations and ecological conditions, we were more interested in the agreement across major differences, instead of such sharp definitions of phases. Actually, succession phases gradually progress to the following ones without abrupt changes, and this difficulty is also experienced in the field, making difficult the phase identification during the phase transition, where age determination becomes an important procedure. For that reason, not all errors had the same importance when we were dealing with multi-attribute subjective decision-making. In this case of model accuracy evaluation, it is more reliable the use of a weighted Kappa measure (Spitzer et al., 1967) which attributes more weight to severe errors than to modest ones. Thus, considering that a weighted version of Kappa should better measure our model accuracy than the overall Kappa we calculated the quadratic weighted Kappa $\left(k^{*}\right)$ for the calibration and validation results. Nevertheless, some shortcomings have been raised to this standard kappa statistics, namely, its inappropriateness to classifications that validate accuracy simultaneously in terms of quantity and location (Pontius, 2000) and also its dependence for prevalence (Forbes, 1995; Fielding and Bell, 1997, Mouton et al., 2010). In order to address this weaknesses, we performed several statistical methods to complement each other in the evaluation, as well as the AUC (Mason and Graham, 2002) that is considered to be generally independent for prevalence (at least at the middle range), despite being highly significantly correlated to kappa (Manel et al., 2001).

The modelling performance by succession phases classification resulted in a $\mathrm{CCl}$ always better than $52 \%$ and even the coefficient of agreement $k$, which is known as a pessimistic statistic (Foody, 1992) revealed at least a good strength of agreement (Landis and Koch, 1977) in the worst case. The $k$ and $k^{*}$ values demonstrated the capacities of the model in the establishment of the phases spatial distribution. Good results were obtained for all the reaches in AUC and sensitivity analysis. The calibration in the Ribeira reach obtained excellent results in terms of correctly predicted negative fraction and falsely predicted positive fraction (specificity and commission rate) for all the stages, while these results were reasonable in the other study sites analyses. In all the study cases, the ACC results were considered satisfactory with maximum values $>0.8$ in most of the cases.

In the Mediterranean climate, where the flood effect is an important source of stress but not the only one, the validation results showed values slightly worse than in the Austrian case study. Nevertheless, it has to be considered that the validation periods (11 years in the Ribeira reach; 17 and 32 years in the Terde reach) were longer in both Mediterranean study sites than in the Austrian case study. The capabilities of the model to distinguish specific riparian vegetation types from others, both succession phases and stages, have been demonstrated. The results were considerable good and similar, not only between both Mediterranean case studies or analyzed periods, but in addition compared to those obtained for the calibration performance evaluation, being in some cases even better. The results obtained as $\mathrm{CCl}(\approx 0.6$ in phases classification and $\approx 0.7$ in stages classification), and ACC $(\approx 0.8$ for advanced stages), verified once more the robustness of the model, its capacities for riparian vegetation distribution establishment in space, also in time, and its 
applicability in different climate regions and in reaches with different hydrological regimes.

The applied model revealed important characteristics that directly contribute to ecologically effective and economically efficient restoration strategies (Palmer et al., 2005). The functional approach based on succession phases, considering colonization strategies and development stage, is highly valuable to overcome the biogeographical limits imposed by species distribution (Lavorel, 2011). This approach enables the application of the model in different climatic and hydrological settings as we showed in the present study. Also, the focus on the maintenance of spatial and temporal functional diversity is crucial because keeping high functional diversity will promote a great deal of riparian ecosystem resilience in the face of environmental changes (Elmqvist et al., 2003). Furthermore, the diversity and ecological integrity of the riparian forest is a relevant factor for other river ecosystem components, for example the water quality, the invertebrates communities and the native fish species richness (Ghermandi et al., 2009; Cortes et al., 2011; Olaya et al., 2011).

The main science gap that promoted this study was the necessity to prove if this model could answer the WFD request for an efficient and common tool useful in the understanding of the riparian vegetation dynamics in different climates and hydrological conditions of the European Framework. The obtained results indicate that extensive application of this model to the generality of European rivers would make possible to intent an implementation of the so emphasized framework for a systematic analysis of river ecosystems (Goodwin and Hardy, 1999). This fact turns this model in a valuable instrument for European member states to assess ecological quality in rivers and achieve its good state. Nevertheless, a spatial validation is considered necessary to assure that the model is capable to accomplish the quality requirements in new study sites.

In terms of efficiency, the model performs in a simplified way the main physical and ecological processes shaping the fluvial patch, and the model outputs are in fact both, spatial (maps) and tabular. These two formats allow immediate visualization, therefore suitable also for non-trained or not scientific personnel, and statistical treatment of the results, which is indeed an interpretation approach closer to the technical and scientific methodology. In addition, this model goes beyond other riparian vegetation models developed to date, as its conceptualization allows a wide applicability and exploitation of its results by different stakeholders including scientific, policymakers and environmental managers.

In the current context of urgent needs for specific restoration strategies embracing an integrated pro-active management policy (EC, 2009), riparian vegetation presents the adequate extension of life cycles acting as a long-timeseries datalogger of multiyear changes. Having an adequate temporal and spatial scale for the prediction of river functioning change, riparian vegetation proved in this study to be an excellent indicator of ecological quality, and a valuable proxy to model river dynamics, to guide management actions and for taking flow management decisions.

\section{ACKNOWLEDGEMENTS}

This work was supported by IWRM Era-NET Funding Initiative through the RIPFLOW project (references ERAC-CT-2005-026025, ERA-IWRM/0001/2008, 
CGL2008-03076-E/BTE), http://www.old.iwrm-net.eu/spip.php, and by the Spanish Ministry of Economy and Competitiveness through the project SCARCE (Consolider-Ingenio 2010 CSD2009-00065).

The Austrian team would like to thank the Lebensministerium (Austrian Ministry of Environment) and Professor Helmut Habersack and his group from the University of Natural Resources and Life Science Vienna for the supply of the hydrological data. The Portuguese team would like to thank António Pinheiro for his supervision of the hydraulic modelling. The hydrological data was supplied by the Portuguese National Hydrologic Resource Information System (SNIRH) and aerial photographs by the Portuguese Geographic Institute (IGP) under the FIGIEE program. Patricia M. Rodríguez-González benefited a post-doctoral grant from FCT (SFRH/BPD/47140/2008). António Albuquerque was a valuable assistant in field work. The Spanish team would like to thank in addition the Hydrological Studies Centre (CEH-CEDEX), the Jucar River Basin Authority $(\mathrm{CHJ})$, and the Spanish National Geographic Information Centre (CNIG) for supplying the hydrological data and the aerial photographs for the Spanish study site.

\section{REFERENCES}

Altier LS, Lowrance R, Williams RG, Inamdar SP, Bosch DD, Sheridan JM, Hubbard RK, Thomas DL. 2002. Riparian ecosystem management model: Simulator for ecological processes in riparian zones. United States Department of Agriculture (USDA). Agricultural Research Service. Conservation Research Report 46, p. 216.

Auble GT, Friedman JM, Scott ML. 1994. Relating riparian vegetation to present and future stream flows. Ecological Applications 4(3): 544-554.

Baptist M, De Jong F. 2005. Modelling the influence of vegetation on the morphology of the Allier, France. In: Cost 626 European Aquatic Modelling Network. Proceedings from the final meeting in Silkeborg, Denmark. Harby et al. (ed.). 19-20 May 2005 Denmark (National Environmental Research Institute): 15-22.

Benjankar R, Egger G, Jorde K, Goodwin P, Glenn NF. 2011. Dynamic floodplain vegetation model development for the Kootenai River, USA. Journal of Environmental Management 92 (2011): 3058-3070. DOI: 10.1016/j.jenvman.2011.07.017

Boavida I. 2007. Análise bidimensional na determinação dos caudais ecológicos - aplicaçãodo modelo River2D. Dissertation for M.Sc. Degree in Hydraulic and Water Resources. Instituto Superior Técnico, Technical University of Lisbon, Lisbon, p. 177.

Bovee KD. 1997. Data collection procedures for the Physical Habitat Simulation System. U. S. Geological Survey, Biological Resources Division. Fort Collins, Colorado. 146 pp.

Bornette G, Puijalon S. 2011 Response of aquatic plants to abiotic factors: a review. Aquatic Science 73: 1-14. DOI: 10.1007/s00027-010-0162-7.

Braatne JH, Rood SB, Simons RK, Gom LA, Canali GE. 2002. Ecology of Riparian Vegetation of the Hells Canyon Corridor of the Snake River: Field Data, Analysis and Modelling of Plant Responses to Inundation and Regulated Flows. Idaho Power Company, Boise, ID, p. 450.

Cohen J. 1960. A coefficient of agreement for nominal scales. Educational and psychological measurement, 20(1): 37-46. DOI: 10.1177/001316446002000104.

Cohen J. 1968. Weighted kappa: Nominal scale agreement provision for scaled disagreement or partial credit. Psychological Bulletin 70 (4): 213-220. DOI: 10.1037/h0026256.

Corenblit D, Baas ACW, Bornette G, Darrozes J, Delmotte S, Francis RA, Gurnell A, Julien F, Naiman RJ, Steiger J. 2011. Feedbacks between geomorphology and biota controlling Earth surface processes and landforms: A review of foundation concepts and current understandings. Earth-Science Reviews 106: 307-331. DOI: 10.1016/j.earscirev.2011.03.002.

Corenblit D, Tabacchi E, Steiger J, Gurnell AM. 2007. Reciprocal interactions and adjustments between fluvial landforms and vegetation dynamics in river corridors: A review of complementary approaches. Earth-Science Reviews 84: 56-86. DOI:10.1016/j.earscirev.2007.05.004 
Cortes R. M., Varandas S., Teixeira A., Hughes S. J., Magalhaes M., Barquín J., Álvarez-Cabria M., Fernández D. 2011. Effects of landscape metrics and land-use variables on macroinvertebrate communities and habitat characteristics. Limnetica 30 (2): 347-362.

Darby S, Sear D. 2008. River restoration: managing uncertainty in restoring physical habitat. John Wiley \& Sons Ltd, p. 315. ISBN: $047086706 X, 9780470867068$

De Baets S, Poesen J, Reubens B, Wemans K, De Baerdemaeker J, Muys B. 2008. Root tensile strength and root distribution of typical Mediterranean plant species and their contribution to soil shear strength. Plant Soil, 305: 207-226. DOI: 10.1007/s11104-008-9553-0.

EC. 2009. Technical report 2009-040. Common Implementation Strategy for the WFD (2000/60/EC). Guidance document no 24. River Basin Management in a changing climate, p. 141.

Egger G, Exner A, Jorde K, Benjankar R. 2009. Impacts of reservoir operations on succession and habitat dynamics: calibration of a dynamic floodplain vegetation model for the Kootenai River, USA. $7^{\text {th }}$ ISE \& $8^{\text {th }}$ HIC. Chile.

Elmqvist T, Folke C, Nystrom M, Peterson G, Bengtsson J, Walker B, Norberg J. 2003. Response diversity, ecosystem change, and resilience. Frontiers in Ecology and the Environment, 1: 488-494. DOI: 10.1890/1540-9295(2003)001[0488:RDECAR]2.0.CO;2.

Fielding $\mathrm{AH}$, Bell JF. 1997. A review of methods for the assessment of prediction errors in conservation presence/absence models. Environmental Conservation 24(1): 38-49.

Fisher K, Dawson H. 2003. Reducing uncertainty in river flood conveyance - roughness review. Department for Environment, Food \& Rural Affairs, Environment Agency. Lincoln, UK, p. 209.

Foody GM. 1992. On the compensation for change agreement in image classification accuracy assessment. Photogrammetric Engineering \& Remote Sensing 58: 1459-1460.

Forbes A. 1995. Classification-algorithm evaluation: Five performance measures based on confusion matrices. Journal of Clinical Monitoring and Computing 11(3): 189-206. DOI: 10.1007/bf01617722.

Formann E, Habersack HM, Schober St. 2007. Morphodynamic river processes and techniques for assessment of channel evolution in Alpine gravel bed rivers. Geomorphology 90: 340-355. DOI: 10.1016/j.geomorph.2006.10.029.

Franz EH, Bazzaz FA. 1977. Simulation of vegetation response to modified hydrologic regimes: A probabilistic model based on niche differentiation in a floodplain forest. Ecology 58: 1176-183. DOI: $10.2307 / 1935119$.

Frissell C, Liss W, Warren C, Hurley M, 1986. A hierarchical framework for stream habitat classification: Viewing streams in a watershed context. Environmental Management 10 (2): 199214. DOI: $10.1007 / B F 01867358$.

Garófano-Gómez V, Martínez-Capel F, Delgado-Artés R. 2009. Les riberes del Serpis. Gestió de l'aigua per a la seua conservació. CEIC Alfons el Vell. Gandia. ISBN 978-84-96839-18-2.

Garófano-Gómez V, Martínez-Capel F, Rodríguez-González P, Rivaes R, Alburquerque A, Ferreira T, Egger G, Politti E, Vallés F, Andrés I. 2011. Analyses of succession-retrogression for dynamic modelling of riparian vegetation in the RIPFLOW project. EGU General Assembly, Vienna. Geophysical Research Abstracts, Vol.13, EGU2011-13094, 2011.

Gergel SE, Dixon MD, Turner MG. 2002. Consequences of human-altered floods, levees, foods, and floodplain forests along the Wisconsin River. Ecological Applications 12: 1755-1770. DOI: 10.1890/1051-0761(2002)012[1755:COHAFL]2.0.CO;2.

Ghermandi A, Vandenberghe V, Benedetti L, Bauwens W, Vanrolleghem PA. 2009. Modelbased assessment of shading effect by riparian vegetation on river water quality. Ecological Engineering 35: 92-104. DOI: 10.1016/j.ecoleng.2008.09.014.

Glenz C. 2005. Process-based, Spatially-explicit Modelling of Riparian Forest Dynamics in Central Europe - Tool for Decision making in River Restoration. PhD. Thesis, Dir.: Rodolphe Schlaepfer. University of Lausanne, Lausanne, Switzerland, p. 220. DOI: 10.5075/epfl-thesis3223.

Goodwin P, Hardy TB. 1999. Integrated simulation of physical, chemical and ecological processes for river management. Journal of Hydroinformatics 1(1): 33-58.

Hagen A. 2002. Technical report: comparison of maps containing nominal data. RIVM project: MAP-SOR S/550002/01/RO, order no. 143699. Maastricht (The Netherlands): Research Institute for Knowledge Systems.

Hooke JM, Brookes CJ, Duane W, Mant JM. 2005. A simulation model of morphological, vegetation and sediment changes in ephemeral streams. Earth Surface Processes and Landforms 30 (7): 845-866. DOI: 10.1002/esp.1195. 
Hupp CR, Rinaldi M. 2010. Human alterations, dynamic equilibrium, and riparian ecosystem responses along selected rivers in Tuscany, Italy (Invited). American Geophysical Union, Fall Meeting 2010, abstract H43E-1298.

Karrenberg S, Blaser S, Kollmann J, Speck T, Edwards PJ. 2003. Root anchorage of saplings and cuttings of woody pioneer species in a riparian environment. Functional Ecology 17: 170177.

Kovalchik BL, Clausnitzer RR. 2004. Classification and management of aquatic, riparian, and wetland sites on the national forests of Eastern Washington: series description. U.S. Department of Agriculture, Forest Service. Portland, U.S. p. 354.

Landis JR, Koch GG. 1977. The measurement of observer agreement for categorical data. Biometrics 33(1): 159-174. DOI: 10.2307/2529310.

Lavorel S, Grigulis K, Lamarque P, Colace M, Garden D, Girel J, Pellet G, Douzet R. 2011. Using plant functional traits to understand the landscape distribution of multiple ecosystem services. Journal of Ecology 99: 135-147. DOI: 10.1111/j.1365-2745.2010.01753.x

Mahoney JM, Rood SB. 1998. Stream flow requirements for cottonwood seedling recruitment An integrated model. Wetlands 18: 634-645. DOI: 10.1007/BF03161678.

Malanson GP. 1993. Riparian Landscapes. Cambridge University Press, 269 p.

Manel S, Williams HC, Ormerod SJ. 2001. Evaluating presence-absence models in ecology: the need to account for prevalence. Journal of Applied Ecology 38(5): 921-931. DOI: 10.1046/j.1365-2664.2001.00647.x.

Mason SJ, Graham NE. 2002. Areas beneath the relative operating characteristics (ROC) and relative operating levels (ROL) curves: Statistical significance and interpretation. Quarterly Journal of the Royal Meteorological Society 128(584): 2145-2166. DOI: 10.1256/003590002320603584.

Medici C, Bernal S, Butturini A, Sabater F, Martin M, Wade AJ, Francés F. 2010. Modelling the inorganic nitrogen behaviour in a small Mediterranean forested catchment, Fuirosos (Catalonia). Hydrology and Earth System Sciences 14: 223-237. DOI: 10.5194/hess-14-223-2010.

Mouton AM, De Baets B, Goethals PLM. 2010. Ecological relevance of performance criteria for species distribution models. Ecological Modelling 221(26): 1995-2002.

Murillo J, Rodríguez Pallarés M, Andrés-Urrutia A, Brufau P, García-Navarro P. 2008. A mathematical model for numerical simulation of shallow water flow: Description and practical application of GUAD 2D. Proceedings of the iEMSs Fourth Biennial Meeting: International Congress on Environmental Modelling and Software (iEMSs 2008). International Environmental Modelling and Software Society, Barcelona, Spain. (3) 1431-1438. ISBN: 978-84-7653-074-0.

Murphy P, Fotherby LM, Randle TJ, Simons R. 2006. Platte River Sediment Transport and Riparian Vegetation Model. U.S. Department of the Interior, Bureau of Reclamation, Technical Service Center, Denver, Colorado.

Naiman RJ, Bunn SE, Nilsson C, Petts GE, Pinay G, Thompson LC. 2002. Legitimizing fluvial ecosystems as users of water: An overview. Environmental Management 30 (4): 455-467. DOI: 10.1007/s00267-002-2734-3.

Naiman RJ, Décamps H, McClain ME. 2005. Riparia: ecology, conservation, and management of streamside communities. Elsevier Academic Press. $430 \mathrm{p}$.

Neitsch SL, Arnold JG, Kiniry JR, Williams JR, King KW. 2002. Soil and Water Assessment Tool theoretical documentation. Version 2000. Texas Water Resources Institute, College Station, Texas, TWRI report, TR-191.

Olaya EJ, Martínez-Capel F, Muñoz-Mas R, Alcaraz-Hernández JD, Soares R, GarófanoGómez V. 2011. Predicting native fish richness in three Mediterranean river basins using artificial neural networks. In: EUROMECH Colloquium 523. Ecohydraulics: linkages between hydraulics, morphodynamics and ecological processes in rivers. Volume of extended abstracts, p. 251-255 (C. Chomette \& J. Steiger, Eds.). ISBN 9-782845-165298.

Oliver CD, Larson BC. 1996. Forest Stand Dynamics. Updated edition, John Wiley \& Sons, Inc., $544 \mathrm{p}$.

Palmer MA, Bernhardt ES, Allan JD, Lake PS, Alexander G, Brooks S, Carr J, Clayton S, Dahm CN, Follstad Shad J, Galat DL, Loss SG, Goodwin P, Hart DD, Hasset B, Jenkinson R, Kondolf GM, Lave R, Meyer JL, O'Donnell TK, Pagano L, Sudduth E. 2005. Standards for ecologically successful river restoration. Journal of Applied Ecology 42: 208-217. DOI: 10.1111/j.13652664.2005.01004.x

Pearlstine LG, McKellar H, Kitchens WM. 1985. Modelling the impacts of a river diversion on the bottomland hardwood communities in the Santee River floodplain. Ecological Modelling 29: 283302. DOI: 10.1016/0304-3800(85)90057-2. 
Perona P, Molnar P, Savina M, Burlando P. 2009. An observation-based stochastic model for sediment and vegetation dynamics in the floodplain of an Alpine braided river. Water Resources Research 45 (9): W09418. DOI: 10.1029/2008WR007550.

Pontius RG. 2000. Quantification Error Versus Location Error in Comparison of Categorical Maps. Photogrammetric Engineering and Remote Sensing 66(8): 1011-1016.

Rayne S, Henderson G, Gill P, Forest K. 2008. Riparian forest harvesting effects on maximum water temperatures in wetland-sourced headwater streams from the Nicola River watershed, British Columbia, Canada. Water Resources Management 22(5): 565-578. DOI: 10.1007/s11269-007-9178-8.

Rood SB, Braatne JH, Hughes FM. 2003. Ecophysiology of riparian cottonwoods: stream flow dependency, water relations and restoration. Tree Physiology 23(16): 1113-1124. DOI: 10.1093/treephys/23.16.1113.

Spitzer RL, Cohen J, Fleiss JL, Endicott J. 1967. Quantification of Agreement in Psychiatric Diagnosis: A New Approach. Archives of General Psychiatry 17(1): 83-87. DOI: 10.1001/archpsyc. 1967.01730250085012.

Stanford JA, Lorang MS, Hauer FR. 2005. The shifting habitat mosaic of river ecosystems. Verhandlungen der Internationalen Vereinigung für Theoretische und Angewandte Limnologie 29: 123-136.

Steffler P, Ghanem A, Blackburn J. 2003. River2D Version 0.90 computer program. University of Alberta, Canada. http://www.River2D.ualberta.ca/index.htm.

Stella JC, Battles JJ, Orr BK, McBride JR. 2006. Synchrony of seed dispersal, hydrology and local climate in a semi-arid river reach in California. Ecosystems 9: 1200-1214. DOI: 10.1007/s10021-005-0138-y.

Stokes A, Atger C, Glyn Bengough AG, Fourcaud T, Sidle RC. 2009. Desirable plant root traits for protecting natural and engineered slopes against landslides. Plant Soil 324: 1-30. DOI: 10.1007/s11104-009-0159-y.

Tabacchi E, Correll DL, Hauer R, Pinay G, Planty-Tabacchi AM, Wissmar RC. 1998. Development, maintenance and role of riparian vegetation in the river landscape. Freshwater Biology 40(3): 497-516. DOI: 10.1046/j.1365-2427.1998.00381.x.

Tockner K, Lorang MS, Stanford JA. 2010. River floodplains are model ecosystems to test general hydrogeomorphic and ecological concepts. River Research and Applications 26: 76-86. DOI: 10.1002/rra.1328.

Tritthart M. 2005. Three-dimensional numerical modelling of turbulent river flow using polyhedral finite volumes. Wiener Mitteilungen Wasser-Abwasser-Gewässer 193: 1-179.

Wildi O. 2010. Data Analysis in Vegetation Ecology. Wiley-Blackwell. West Sussex, UK. 211 pp.

Wu R, Mao C. 2007. The assessment of river ecology and habitat using a two-dimensional hydrodynamic and habitat model. Journal of Marine Science and Technology 15(4): 322-330. 